\title{
"PER CLERUM ET POPULUM"? LEGAL TERMINOLOGY AND EPISCOPAL APPOINTMENTS IN DENMARK 1059-1225
}

\author{
BY ANNA MINARA CIARDI
}

The phrase per clerum et populum ("by clergy and people") was traditionally used to describe how the election of a bishop had been or should be undertaken. Over the course of the twelfth century this changed. Ecclesiastical legislation was step by step revised and codified. The aim of the reformers was to safeguard the autonomy of the Church and to reduce lay influence. The purposes of this article are, first, to examine legal terminology in the context of episcopal appointments from 1059 to 1215 , with special reference to the formula per clerum et populum and the role of cathedral chapters as electoral bodies; second, to examine how episcopal appointments were actually undertaken and what terminology was used in the kingdom of Denmark until circa 1225; and, third, to share some ideas about the development of canon law in the context of "cathedral culture." My conclusions are, first, that the mode of election per clerum et populum was gradually replaced and eventually became invalid, parallel to a legal development where cathedral chapters became the "proper" electoral body; second, that the monastic ideals of ecclesiastical freedom prompted by the reformers are evident in normative texts from cathedral chapters in Denmark already in the first quarter of the twelfth century; and, finally, that the legal developments strongly contributed to the formation of capitular institutions and a specific cathedral culture, which was rooted in monasticism but also differed from it, not least with regard to its legal functions.

\section{INTRODUCTION}

The appointment of bishops is a fruitful topic for someone studying the early development of cathedral chapters. This is especially true with regard to the period from the mid-tenth to the early thirteenth century, which is not a period of mere legal transition or clarification but one in which legal and organizational matters underwent decisive changes. The impetus for this process was first and foremost the harsh debates over papal power, lay influence, and ecclesiastical freedom and reform that ravaged Latin Christendom in the eleventh century. Of crucial importance to all contestants involved was the question of episcopal appointments. Not only did the legal, ecclesiastical, and political turmoil over the episcopal office involve key figures like Pope Gregory VII (d. 1085) and the German Emperor Henry IV (d. 1106); local churches and societies throughout Europe were also affected. ${ }^{1}$

This article is a revised version of part of my dissertation, entitled "On the Formation of
Cathedral Chapters and Cathedral Culture: Lund, Denmark, and Scandinavia, c. 1060-1225."
1 On the popes Leo IX (d. 1054) and Gregory VII in the context of ecclesiastical reform,
see, for example, Ian S. Robinson, The Papal Reform of the Eleventh Century: Lives of Pope Leo 
This article takes as its point of departure the phrase per clerum et populum ("by clergy and people"), which was traditionally used to describe how an episcopal election had been or should be undertaken. Had a bishop been elected per clerum et populum, then his appointment had been properly undertaken and was to be considered canonical and valid. In the course of the twelfth century, this changed. In order to comprehend the legal transformation and its impact, one must bear in mind that no codified and universally valid procedure for episcopal appointments had previously existed. From the beginning of the twelfth century onward, however, ecclesiastical legislation was revised, altered, and codified step by step, the driving force being the urge for libertas ecclesiae, ecclesiastical freedom, and the desire to prompt measures directed toward this end. The aim of the reformers was to safeguard the autonomy of the Church and reduce what they considered to be improper lay influence. ${ }^{2}$

IX and Pope Gregory VII (Manchester, 2004), esp. 1-95.

Throughout the notes, the following abbreviations are used:

Adam of Bremen, Gesta Hammaburgensis ecclesiae pontificum = Adam of Bremen, Gesta Hammaburgensis ecclesiae pontificum, ed. Bernhard Schmeidler, in Scriptores rerum germanicarum in usum scholarum ex monumentis germaniae historicis separatim editi, MGH SRG 2 (Hanover, 1917).

Chronicon Roskildense $=$ Chronicon Roskildense, ed. Martin Clarentius Gertz, in Scriptores minores historiae Danicae Medii aevi (Copenhagen, 1917-18), 1:1-33.

$\mathrm{CIC}=$ Corpus iuris canonici, ed. Emil Friedberg and Emil Ludwig Richter, 2 vols. (Leipzig, 1879-81; repr. Graz, 1959).

Constantinople IV (869-870) = "Constantinople IV (869-870)," in Decrees of the Ecumenical Councils, vol. 1, Nicaea I to Lateran V, ed. Norman P. Tanner (London, 1990), 157-86.

Consuetudines Lundenses $=$ Consuetudines Lundenses: Statutter for kannikesamfundet $i$ Lund c. 1123, ed. Erik Buus (Copenhagen, 1978), 109-78.

Cronica ecclesice Ripensis $=$ Cronica ecclesice Ripensis $($ Ribe Bispekronike $)$, ed. Ellen Jørgensen, in Kirkehistoriske Samlinger (Copenhagen, 1933-35), 6.1:23-33.

Danmarks Riges Breve, ed. Franz Blatt and Gustav Hermansen (Copenhagen, 1938-).

Dipl. Dan. = Diplomatarium Danicum, ed. Niels Skyum-Nielsen et al. (Copenhagen, 1938-).

Dipl. Suec. $=$ Diplomatarium Suecanum $=$ Svenskt diplomatarium, ed. Johan Gustaf Liljegren et al. (Stockholm, 1829-).

Lateran I (1123) = "Lateran I (1123)," in Decrees of the Ecumenical Councils, vol. 1, ed. Tanner (London, 1990), 187-94.

Lateran II (1139) = "Lateran II (1139)," in ibid., 195-205.

Lateran III (1179) = "Lateran III (1179)," in ibid., 205-25.

Lateran IV (1215) = "Lateran IV (1215)," in ibid., 227-71.

Reg. Norv. = Regesta Norvegica, vol. 1, 991-1263, ed. Gustav Storm, Det Norske historiske kildeskriftfond (Oslo, 1898-), http://www.dokpro.uio.no/dipl_norv/regesta_felt.html.

Saxo Grammaticus, Gesta Danorum = Saxo Grammaticus, Gesta Danorum: History of the Danes, ed. Karsten Friis-Jensen, trans. Peter Fisher, Oxford Medieval Texts (Oxford, 2015). This project has been partly financed by Ebbe Kock's Foundation, Lund.

2 On the development of a universal and codified ecclesiastical law in the West, see, e.g., Willibald M. Plöchl, Geschichte des Kirchenrechts, vol. 2, Das Kirchenrecht der abendländischen Christenheit: 1055 bis 1517 (Vienna, 1962); John Gilchrist, Canon Law in the Age of Reform, 11th-12th Centuries, Collected Studies Series 406 (Aldershot, 1993); Richard H. Helmholz, 
My purposes are, first, to examine legal terminology in the context of episcopal appointments from 1059 to 1215 with special reference to the formula per clerum et populum; second, to examine how episcopal appointments were actually undertaken and what terminology was used in the kingdom of Denmark until circa 1225; and, third, to share some conclusions about the development of canon law in the context of "cathedral culture," a concept I will explain further below.

As for the temporal limits of this study, the reason for choosing the year 1059 as the starting point of my examination is that this is the year when King Sven Estridson (d. 1074) reorganized the Danish church and established a diocesan organization that lasted throughout the Middle Ages. ${ }^{3}$ I have chosen the year 1225 as the closing year because just before then (1224) we have documentation that shows the immediate effects on Danish practice of the relevant decrees from the Fourth Lateran Council of 1215, which at the time were the closest thing to a codified universal ecclesiastical law, that is, before the Decretals of Pope Gregory IX, known as the Liber Extra, were published in $1234 .{ }^{4}$ Clearly, this was not the last stage in the development of legislation concerning episcopal elections. ${ }^{5}$ At the same time, however, it seems to be the end of the ideal of episcopal appointments and elections per clerum et populum in Denmark.

The Spirit of Classical Canon Law (Athens, GA, 1996); and Greta Austin, "Bishops and Religious Law, 900-1050," in The Bishop Reformed: Studies of Episcopal Power and Culture in the Central Middle Ages (Ashgate, 2007), 40-57.

3 The dating is based on Michael H. Gelting, "Elusive Bishops: Remembering, Forgetting, and Remaking the History of the Early Danish Church," in The Bishop: Power and Piety at the First Millennium, ed. Sean Gilsdorf (Münster, 2004), 169-200 at 187-92. See also idem, "The Kingdom of Denmark," in Christianization and the Rise of Christian Monarchy: Scandinavia, Central Europe and Rus' c. 900-1200, ed. Nora Berend (Cambridge, 2007), 73-120 at 94-95. On the reorganization of the Danish church, see below. The episcopal see of Dalby was later abolished and subordinated to Lund.

4 Bernhard Schimmelpfennig, "The Principle of the Sanior Pars in the Election of Bishops during the Middle Ages," Concilium 137 (1980): 16-23, at 18-21. Cf. Paul B. Pixton, The German Episcopacy and the Implementation of the Decrees of the Fourth Lateran Council 1216-1245: Watchmen on the Tower, Studies in the History of Christian Thought 54 (Leiden, 1995), esp. 220-318.

5 Cf. Jean Gaudemet et al., Les élections dans l'église latine des origines au XVIe siècle (Paris, 1979), 106-92; Helmholz, The Spirit of Classical Canon Law, 46-52. For an overview of the growth of ecclesiastical legislation, see, for example, James A. Brundage, Medieval Canon Law (London, 1995), esp. 5-69; idem, The Medieval Origins of the Legal Profession: Canonists, Civilians, and Courts (Chicago, 2008), 63-151; Kenneth Pennington, "The Decretalists 1190-1234," in The History of Medieval Canon Law in the Classical Period, 1140-1234, vol. 3, From Gratian to the Decretals of Pope Gregory IX, ed. Wilfried Hartmann and Kenneth Pennington, History of Medieval Canon Law (Washington, DC, 2008), 121-245; Charles Duggan, "Decretal Collections from Gratian's Decretum to the Compilationes antiquae: The Making of New Case Law," in ibid., 246-92; and Kenneth Pennington, "Decretal Collections 1190-1234," in ibid., 293-317. 


\section{The Bishop}

Already in the early Church, episcopal appointments drew the attention of legal authorities and were regulated in the nascent legal corpus of the Church, that is, in passages from Scripture and the Church Fathers, in the canons of local and provincial synods, and in episcopal and papal letters. ${ }^{6}$ The attention that was afforded this question is not to be wondered at, since bishops were regarded as representatives of Christ himself, wielding both spiritual and temporal authority over the faithful.

The local bishop became one of the most prominent persons in the medieval Church and society. His primary functions were to be the spiritual head of his diocese, a shepherd, and a judge; gradually, however, more functions were added: as a secular ruler, the bishop played a decisive role in society as landlord and member of the local government; thanks to his position and, usually, his bonds of kinship, he belonged to the elite of society and was included in the most significant social networks; and, thanks to his office, he might exert influence as royal counselor, diplomat, or even military commander. In the church he was a bond of unity, connecting the parish to the diocese and the diocese to the universal Church. From the point of view of Rome, he was a symbol of the unity and catholicity of the Church, a unity that extended even to geographically remote areas. To the king, he was an indispensable ally and, furthermore, an authority able to legitimize royal power. To ordinary people, he was a physical link with the universal Church and an august pastor who confirmed their children, consecrated their churches, and was the guardian of true doctrine and right discipline. ${ }^{7}$ Thus, it was vital to the interests of many that the right person was, so to speak, contracted for the job.

6 Cf. Peter Stockmeier, "The Election of Bishops by Clergy and People in the Early Church," Concilium 137 (1980): 3-9. Cf. Episcopal Appointments, Ecclesiastical Law, and Legal Proceedings Until 1123, below.

7 The major functions of the medieval bishop were to perform consecrations and ordinations, to be a guardian of the Christian faith and of ecclesiastical discipline, and to administer the property of the church ("potestas ordinis," "potestas magisterii," and "potestas iurisdictionis"). See K. Richter, "Bischof," in Lexikon des Mittelalters (Munich, 2002) 2:cols. 228-38. On the bishop's relation to lay power and his position in medieval society, see, e.g., Helmholz, The Spirit of Classical Canon Law, 36; Steffen Patzold, Episcopus: Wissen über Bischöfe im Frankreich des späten 8. bis frühen 10. Jahrhunderts, Mittelalter-Forschungen 25 (Ostfildern, 2009); and Katherine Harvey, Episcopal Appointments in England, c. 1214-1344: From Episcopal Election to Papal Provision, Church, Faith and Culture in the Medieval West (Farnham, 2014). 
Episcopal Appointments, Ecclesiastical Law, and Legal Proceedings until 1123

How, then, were these prominent men to be appointed — and by whom? As was stated above, there existed no codified universal law dealing with these questions until the end of the period at issue. The significance of the outcome, however, prompted action and some degree of regulation already in the early days. ${ }^{8}$ One of the earliest indications of lay influence on episcopal elections is found in connection with St. Cyprian (d. 258), who himself was appointed bishop of Carthage thanks to lay interference. ${ }^{9}$ With reference to the arguments and sources provided by François Hallier, who presented a wide range of citations, from the Acts of the Apostles to local synodal decrees from the fourth and fifth centuries, the distinguished legal historian Richard H. Helmholz states that:

The best attested and perhaps also the oldest rule of the church held that the choice of bishops should be made per clerum et populum. ... It was, and remains, far from clear what this venerable formula, requiring some combination of assent from the clergy and people actually meant in the earliest days. ... It may be that they regarded the real choice as belonging to God, the voice of the clergy and people being simply the way in which God's selection was ordinarily made manifest. ${ }^{10}$

As Helmholz and, before him, Robert L. Benson and others have pointed out, it seems that there was no need to define the electoral body in detail at this point; "by clergy and people" was enough. ${ }^{11}$ Also, from the preserved sources it is

8 More generally on the episcopal elections in the early Church see Stockmeier, "The Election of Bishops." On episcopal appointments and elections and lay influence, see, e.g., Roland Em, Les chanoines et les élections épiscopales du XIe au XIVe siècle: Étude sur la restauration, l'évolution, la décadence du pouvoir capitulaire; 1080-1350 (Aurillac, 1909); Robert L. Benson, The Bishop Elect: A Study in Medieval Ecclesiastical Office (Princeton, 1968); Gaudemet et al., Les élections; Helmholz, The Spirit of Classical Canon Law, 33-60; Jean Gaudemet, "The Choice of Bishops: A Tortuous History," Concilium 5 (1996): 59-65; Thomas Heinz et al., "Wahl," in Lexikon des Mittelalters 8:cols. 1909-11; Anne Duggan, "Ecclesiastical Succession: Canon Law and Compromise in Post-conquest England," in Making and Breaking the Rules: Succession in Medieval Europe, c. 1000-c.1600, ed. Frédérique Lachaud and Michael Penman, Histoire de familles: La Parenté au Moyen Age 9 (Turnhout, 2008), 175-90; and Harvey, Episcopal Appointments.

9 Stockmeier, "The Election of Bishops," 6; Francis A. Sullivan, "St. Cyprian on the Role of the Laity in Decision Making in the Early Church," in Common Calling: The Laity and Governance of the Catholic Church, ed. Stephen J. Pope (Washington, DC, 2004), 39-49 at 39-42.

10 Helmholz, The Spirit of Classical Canon Law, 35, referring to François Hallier, De sacris electionibus et ordinationibus ex antiquo, et novo Ecclesiae usu, 2nd ed. (Rome, 1740), 1:sect. 1, chap. 3, $§ 1,101-8$ (with source references). A more accessible and recent list of sources for the period is found in Gaudemet et al., Les élections, 13-48. See also Stockmeier, "The Election of Bishops," 4-5.

11 Benson, The Bishop Elect, 24-27; Helmholz, The Spirit of Classical Canon Law, 35. 
hard to draw any substantial conclusions about how to identify either "clergy" or "people." As regards the definition, Willibald M. Plöchl has suggested that in the early Church, "clergy" ("clerus") should be understood as anyone belonging to the ranks of ordained men whereas "people" ("populus") were those who did not so belong and had no liturgical functions, but were members of the local community. This observation is supported by, for example, Michael Buckley, who argues that the instruction for episcopal appointments in the Didache (ca. 100) "addresses all of those who participate in the Eucharist." 12 According to Plöchl, one should not exaggerate or overinterpret a state of opposition between the two groups in the early days. ${ }^{13}$ According to Francine Cardman, "The concepts of 'laity' and 'clergy' had no place in the earliest churches founded by the apostles and other missionary preachers." Instead, she says, "the rapid elaboration of ecclesiastical structures and hierarchy," and especially from the reign of Constantine and onwards, prompted “distinctions between 'laity' and 'clergy." 14 This indicates that lay influence on the electoral procedure was not only accepted but, at this point, even regarded as a token of a canonical and thus valid process. The mutual and unanimous election of a candidate, not the formulation of a precise definition of the electoral body and its composition, was imperative. ${ }^{15}$

A somewhat different impression is given by the formulation in a decree of the First Council of Nicaea (325) that Hallier's exposé omits. In can. 4, the Conciliar Fathers declared that "a bishop should be appointed by all the bishops of the province"; if it is not possible for them all to gather and perform the election, "all bishops shall have taken part in the vote and given their written consent."16 It is not clear whether the bishops were meant to form an electoral body; perhaps their role was just to approve and ordain a previously elected

12 Michael Buckley, "Resources of Reform from the First Millennium," in Common Calling, ed. Pope, 71-86 at 72-76, citation at 72 .

13 Willibald M. Plöchl, Geschichte des Kirchenrechts, vol. 1, Das Recht des ersten christlichen Jahrtausends: Von der Urkirche bis zum grossen Schisma, 2nd ed. (Vienna, 1960), 62-63. According to Plöchl, it is hard to draw any certain conclusions. In the case of "clergy," he refers to St. Jerome, Letter 52, "Ad Nepotianum de vita clericorum et monachorum."

14 Cf. Francine Cardman, "Laity and the Development of Doctrine," in Common Calling, $51-69$ at $52-55$, citation at 53 .

15 Cf. Buckley, "Resources of Reform"; Sullivan, "St. Cyprian."

16 This is Tanner's translation of the Greek text. The Latin translation uses the verbs ordinare, decernere, and consentire, which do not give the impression that they take part in a vote, but that they approve the elected candidate and ordain him: "Episcopum convenit maxime quidem ab omnibus qui sunt in provincia episcopis ordinari. Si autem hoc difficile fuerit, aut propter instantem necessitatem aut propter itineris longitudinem: modis omnibus tamen tribus in id ipsum convenientibus et absentibus episcopis pariter decernentibus et per scripta consentientibus tunc ordinatio celebretur. Firmitas autem eorum, quae geruntur per unamquamque provinciam, metropolitano tribuatur episcopo." "Nicaea I (325)," in Decrees of the Ecumenical Councils, vol. 1, ed. Tanner, can. 4 (p. 7). 
candidate. Nevertheless, the authoritative powers of the Church in 325 seem to have tried to safeguard that those in the highest ranks of the Church, and not clerics in general, should wield decisive influence over episcopal appointments. ${ }^{17}$ Even so, we do not know exactly how elections were conducted and what role laymen may have played in them. Helmholz summarizes these tensions by admitting that "there has been a long scholarly controversy about the respective roles accorded to the opinions of the neighboring bishops, the clergy of the diocese, monastic leaders, and the people to be governed by the man elected." 18

It is evident that episcopal appointments throughout history often became a source of conflict - either within the ranks of the Church itself or between ecclesiastical and secular authorities. In order to preserve the unity of the Church, such conflicts had to be legally settled. There are legal sources pointing toward a development where, on the one hand, the method of "election" was kept in order to safeguard the canonicity of the procedure, but, on the other hand, the process came to involve new agents as the circle of electors was in one respect widened and in another respect narrowed: at times, "the people" came to be represented by the secular ruler alone. According to Helmholz, there are indications of such developments in papal letters from the days of Pope Celestine I (d. 432) and Pope Leo I (d. 461). Helmholz suggests that by writing "No bishop is to be given to the unwilling" Celestine I provided a scope for princely consent, whereas Leo I acknowledged an active lay participation in the process by writing "Let him who is to rule over all be elected by all." 19 The political situation in the Roman Empire was unstable. Soon lay influence and intervention came to characterize the process of episcopal appointments, first in the East and later in the West. In the East, the form of government known as caesaropapism even presupposed that the emperor was both spiritual and temporal ruler and therefore was entitled to appoint bishops. ${ }^{20}$ In the West, however, the situation was different, not least as a result of the lack of secure and stable secular government. Accordingly, there was an impulse for further definitions and restrictions, which tended to vary in relation to geographical areas and regional needs. In the Iberian Peninsula, for example, royal influence over episcopal appointments

17 Cf. Stockmeier, "The Election of Bishops," 7: "The important fourth canon of the Ecumenical Council of Nicaea enjoined that a bishop should in principle be installed by all his episcopal colleagues in the same eparchy."

18 Helmholz, Spirit of Classical Canon Law, 35.

19 Ibid. Recently, Katherine Harvey has interpreted the same papal letters as evidence of how "the principle of free elections was confirmed" by both pontiffs. She argues that "the principle of free election was confirmed by the responsa of Popes Celestine I and Leo I in the fifth century." In my opinion, that is a somewhat anachronistic interpretation. In addition, Harvey seems to be unaware of Helmholz's survey, which is unfortunate as it would have supported her own; see Harvey, Episcopal Appointments (n. 7 above), 12 with n. 4.

20 Benson, The Bishop Elect; Richter, "Bischof" (n. 7 above). 
seems to have been considered both natural and desirable. One of the decrees of the Twelfth Council of Toledo (681) refers to "the prince's free choice" ("libera principis election") and declares that the archbishop should approve of "whomever the royal power chooses" ("quoscumque regalis potestas elegerit"). ${ }^{21}$

A similar development is found in those new dynasties that arose in the West at about the same time, that is, the Merovingian and Carolingian kingdoms. ${ }^{22}$ Here, the formula "by clergy and people" was indeed considered to be the unassailable principle of canonical, that is, valid, elections. ${ }^{23}$ As a consequence of the specific ecclesiastical organization that prospered there, known as the Eigenkirchensystem, lay influence on the process was gradually increased, recognized, and codified as consensus civium. In addition, with the "quasi-priestly position" ("quasipriestliche Stellung") of the Merovingian and Frankish kings, the "people" with the ruler in the front line - gained more and more influence, and its participation in the election came to be a prerequisite of ecclesiastical appointments. ${ }^{24}$ However, no ecclesiastical criticism seems to have been leveled at Charlemagne (d. 814), who was accustomed not only to approve of the electus but also to exert great influence on the outcome of the electoral process. This "local" Western tradition was bequeathed to his Ottonian and Salian successors, who exerted more or less full control over episcopal appointments. ${ }^{25}$

The matter was also on the agenda in the East: the Fourth Council of Constantinople (869-870) laid down that the "nomination and consecration of bishops ... as a result of the power and intrigues of the civil authorities" was forbidden (can. 12 ) and that "the promotion and consecration of bishops should be done by means of an election and decision of the college of bishops" (can. 22). ${ }^{26}$ This was undoubtedly a reaction to the fact that the ecclesiastical authorities considered secular powers to have violated their rights, especially since secular rulers not only saw

21 Benson, The Bishop Elect, 26.

22 On the documentation for the period, see Gaudemet et al., Les élections (n. 5 above), 49-104.

23 On the concept of "canonical elections," cf. Episcopal Appointments, Ecclesiastical Law, and Legal Proceedings, 1123-1215, below. By "canonical," I here mean "in accordance with the canons of conciliar decrees and other legal documents."

24 Jean Gaudemet, "Bishops: From Election to Nomination," Concilium 137 (1980): 1015, at 11. Richard Schneider, "Wechselwirkungen von kanonischer und weltlicher Wahl," in Wahlen und Wählen im Mittelalter, ed. Richard Schneider and Harald Zimmermann, Vorträge und Forschungen 37 (Sigmaringen, 1990), 135-71 and esp. 138-40. On bishops and episcopal appointments in the Carolingian era, see, e.g., Patzold, Episcopus (n. 7 above).

25 Schneider, "Wechselwirkungen," 139-40. Cf. Gaudemet et al., Les élections, 105-19.

26 "Promotiones et consecrationes episcoporum et potentia et praeceptione principum factas penitus interdicentibus, concordantes definimus et sententiam nos quoque proferimus," Constantinople IV (869-870), can. 12 (p. 175); and can. 22 (p. 182): "Promotiones atque consecrationes episcoporum, concordans prioribus conciliis, electione ac decreto episcoporum collegii fieri sancta haec et universalis synodus definit et statuit." 
themselves as entitled to approve of the episcopal candidates but more and more frequently appointed and installed bishops themselves.

From the mid-eleventh century, not least due to problems regarding the appointment of bishops as manifested in the so-called Investiture Controversy, the claim for "ecclesiastical freedom" came to the fore. In numerous synods and councils, the mode of election and appointment was emphasized and the requirements of fit candidates were fervently discussed, together with the concept of "canonical." According to the reformers, the custom of investiture, the existence of simony, violence, or threats, and long-term vacancies laid bare the inappropriateness of lay influence and the detrimental effects of unfit candidates. ${ }^{27}$ The agents in these processes were many: on the one hand, there were the resilient popes, who prompted ecclesiastical reform, aspired to gain control over the Church and centralized the settlement of vital ecclesiastical issues, among them episcopal appointments; on the other hand, there were powerful and influential princes like the German rulers, who wished to select their own candidates for episcopal office in their realm and, at times, also for the papal office. ${ }^{28}$ Altogether, there was a strong wish to reduce inappropriate lay intervention in the act of election or appointment but certainly not to exclude lay influence itself. Instead, the formula per clerum et populum had a revival. In the Gregorian reform — or "the Papal Revolution" - the reformers insisted that the bishop should be elected "by clergy and people." They argued that this was in line with ecclesiastical tradition, and, as long as none of the parties exceeded its authority, there should be no problem about canonicity, which seems to have been the fundamental purpose. Yet, in the eyes of the reformers, the arguments for "free elections" grew stronger.

The initial and renewed emphasis on elections "by clergy and people" should, according to Benson, be considered as "a conservative reaction against the misuse of princely power in ecclesiastical elections." ${ }^{.29}$ But in fact no universal solution for how to perform a "free" election existed at this point. Indeed, in some places the cathedral clergy alone were entitled to perform the election.

27 Helmholz, The Spirit of Classical Canon Law, 35-36 with n. 13, and reference to Colin Morris, The Papal Monarchy: The Western Church from 1050 to 1250, Oxford History of the Christian Church (Oxford, 1989), 118-19. Helmholz refers to the Lenten synod in 1080. For more on Gregory VII's attitude regarding lay investiture and the Lenten synods, see his pontificate in Benson, The Bishop Elect, 217-25; and Schneider, "Wechselwirkungen."

28 "The effort was more than a simple struggle for power between church and state. From the point of view of the reformers, few things mattered more than placing the best men in positions of leadership ... The history of disputes over who should be chosen bishop was filled with examples of acrimonious divisions between partisans of this or that candidate. This unseemly squabbling was something reformers in the church were determined to eliminate if they could, to minimize if they could not." Helmholz, The Spirit of Classical Canon Law, 34.

29 Benson, The Bishop Elect, 27; Gaudemet, "Bishops," 10-11. 
Both these perspectives are still found in the 1140s in Gratian's Decretum. ${ }^{30}$ Helmholz writes: "In 1140, no procedure or papal bureaucracy existed that would have been capable of selecting men in far-off sees whenever an incumbent died." 31

Benson sums up the ecclesiastical developments and legal proceedings up to the settlement of the Investiture Controversy as follows:

In the eleventh century, "election by clergy and people" became a slogan of the reformers. At first the program behind this slogan implied no necessary attack on princely and lay rights, for it was originally a simple demand that clergy and people should be consulted in the selection of a bishop, and at least allowed to register their approval. During the third quarter of the century, however, reformers began to insist that the clergy should have the initiative in electing the bishop, and therewith the reformers' program was aiming toward the exclusion of all direct lay participation in ecclesiastical elections. Yet, to most people during the eleventh and early twelfth centuries, canonical election by the "clergy and people" implied the election or at least the consent of all concerned: canons of the cathedral chapter, cathedral and monastic clergy, nobility, ministeriales, and citizens. ${ }^{32}$

In 1122, the Worms Concordat between Pope Calixtus II (d. 1124) and the German Emperor Henry V (d. 1225) settled part of the conflict. According to the concordat, the emperor renounced the privilege of confirming the election through spiritual investiture ("spiritualia"), that is, the crozier and the ring, which was reserved for the archbishop/pope; but he was granted the power to confer lay investiture ("regalia") through the scepter. In addition, the prince should obey the bishop in spiritual matters. The status of the Worms Concordat is much debated, and nothing explicit is said in it about the electoral procedure itself except that elections should be performed canonically, without simony, violence, or exactions and that consecrations should be free. ${ }^{33}$ We hear of no electoral

30 On the concept of "the Papal Revolution" see, for example, Helmholz, The Spirit of Classical Canon Law, 33. Cf. Schneider, "Wechselwirkungen.” On Gratian see, e.g., Helmholz, The Spirit of Classical Canon Law, 37-39, 42-45.

31 Ibid., 39.

32 Benson, The Bishop Elect, 27.

33 Ibid., 228-50. The Concordat of Worms in MGH Const. 1, nos. 107-08, 159-60: "Que in regno vel imperio meo sunt, canonicam fieri electionem et liberam consecrationem" (citation at 159). In this period, the Concordat of Worms was not the only one of its kind. In England we find the Concordat of London in 1107 between King Henry I and the English Church (however with archbishop Anselm of Canterbury absent). See Constitutions of Clarendon, "Concordat of London 1107 and Clause 12 of the Constitutions," accessed 12 December 2015, http://conclarendon.blogspot.se/2013/06/concordat-of-london-1107.html. The Concordat of Sutri of 1111 between Pope Calixtus II and Emperor Henry V has been considered a prototype for the Concordat of Worms. 
body. Even if the concordat had no universal legitimacy, it was widely recognized, not least because it delineated the power relations between pope and prince in the context of ecclesiastical appointments. ${ }^{34}$ But a universal solution remained a strong desideratum.

Of more direct legal significance were the four subsequent Lateran councils whose decrees were later incorporated into official collections of decretals, the formally valid canon law of that time. ${ }^{35}$ Much was achieved at these councils, both with regard to the codification of canon law and with respect to the creation of a legal procedure for episcopal elections. ${ }^{36}$

Still, in the decrees of the First Lateran Council in 1123, which was an immediate response to the Worms Concordat, no novelties were promulgated. Nothing was said about to whom the right to carry out the election pertained but only that the bishop must be "canonically elected." 37

34 On the Concordat of Worms and its later influence on the concepts of spiritual and secular investiture, see Benson, The Bishop Elect, 303-72. On the reception and influence of the Concordat in England, Harvey writes: "Elections were typically conducted in a manner that echoed the Concordat of Worms (1122), a text that was circulated widely in England and demanded election in the royal presence, with any disputes to be settled "by the judgment and counsel of the archbishop and the bishops of the province." Harvey, Episcopal Appointments (n. 7 above), 14. Cf. Anne Duggan, "Ecclesiastical Succession" (n. 8 above).

35 On councils and new law — and the Third Lateran Council (1179) in particular — see Danica Summerlin, "The Reception and Authority of Conciliar Canons in the Later-twelfth Century: Alexander III's 1179 Lateran Canons and Their Manuscript Context," Zeitschrift der Savigny-Stiftung für Rechtsgeschichte, Kan. Abt. 100 (2014): 112-31.

36 In this essay, I have confined myself to the Lateran councils as the highest judicial assembly of the period. It is possible that a closer study of papal decretals issued in the period under consideration would yield more detailed results concerning the development of legislation about episcopal elections. However, I here wish to focus on conciliar legislation because of its undisputed universal scope. See n. 5 and the references to Pennington's and Duggan's works. The legal reflection on episcopal elections in, for example, Gratian, has been examined by others, e.g., Benson, The Bishop Elect; Helmholz, The Spirit of Classical Canon Law, 32-60; Anders Winroth, The Making of Gratian's Decretum, Cambridge Studies in Medieval Life and Thought, 2nd ed. (Cambridge, 2002), 4:49; and Thibault Joubert, "L'élection épiscopale dans le décret de Gratien: Un example de tradition canonique," Studia canonica 49 (2015): 357-78. On the biography of Gratian, see Anders Winroth, "Where Gratian Slept: The Life and Death of the Father of Canon Law," Zeitschrift der Savigny-Stiftung für Rechtsgeschichte, Kan. Abt. 99 (2014): 105-28. Winroth's conclusions have been discussed by Kenneth Pennington, who attributes the final version of the Decretum to Gratian himself, Kenneth Pennington, "The Biography of Gratian, the Father of Canon Law," Villanova Law Review 59 (2014): 679-706.

37 "Nullus in episcopum nisi canonice electum consecret. Quod si praesumptum fuerit, et consecratus et consecrator absque recuperationis spe deponatur." Lateran I (1123), can. 3. 
Episcopal Appointments, Ecclesiastical Law, and Legal Proceedings 1123-1215

In 1139, at the time of the Second Lateran Council, which had been convoked by Pope Innocent II (d. 1143), a more elaborate model was decreed. ${ }^{38}$ Even so, out of thirty canons only one referred to the election of bishops. In can. 28 it is established that the election should be held within three months of the beginning of the vacancy and that "the canons of the episcopal see" are strictly forbidden "to exclude religious men ["viri religiosi"] from the election." Instead, they should elect "a virtuous and suitable person as bishop" with the advice of these men; if these religious men are excluded without their own assent, the election is null and void. Here we find serious attempts to define an electoral body and a certain disregard for the possible participation of laymen in the election process. In addition, at this point it seems to have been taken for granted that the cathedral clergy — referred to as canons — played a primary role in episcopal elections, making this one of the oldest references to the cathedral clergy as an electoral body. Perhaps this should be considered as a clarification of the brief formulation in can. 3 of the First Lateran Council. ${ }^{39}$

The Third Lateran Council in 1179, summoned by Pope Alexander III (d. 1181), introduced even more technical details, for example about the age and character of the candidate. On the topic of electoral procedure, we read in can. 3 about appointments to ecclesiastical offices: "and let these appointments be made by the chapter, or by the metropolitan, if the chapter cannot agree." The exclusion of lay participants is explicit, and the existence of a chapter is again more or less taken for granted. But nothing is said about the electoral body in episcopal elections nor about how the election of a bishop should be confirmed. ${ }^{40}$

38 For more on conciliar law in this period, see Anne Duggan, "Conciliar Law 1123-1215: The Legislation of the Four Lateran Councils," in The History of Medieval Canon Law (n. 5 above), 318-78. For more specific information on the German church and ecclesiastical legislation before the Fourth Lateran Council, see Pixton, The German Episcopacy (n. 4 above), 90-183.

39 "Obeuntibus sane episcopis, quoniam ultra tres menses vacare ecclesias prohibent patrum sanctiones, sub anathemate interdicimus, ne canonici de sede episcopali ab electione episcoporum excludant religiosos viros, sed eorum consilio honesta et idonea persona in episcopum eligatur. Quod si exclusis eisdem religiosis electio fuerit celebrata, quod absque eorum assensu et convenientia factum fuerit, irritum habeatur et vacuum." Lateran II (1139), can. 28.

40 "Et per capitulum aut per metropolitanum, si capitulum concordare nequiverit, ordinentur." Lateran III (1179), can. 3, pp. 212-13. In the final section of the canon it is decreed that if clerics have elected someone in opposition to the aforementioned, they can expect a severe punishment and suspension for at least three years; if a bishop has appointed ecclesiastical officials in opposition to the decrees, the right of appointment shall be transferred to the chapter or to the metropolitan, if the chapter cannot agree. Cf. Schimmelpfennig, "The Principle of the Sanior Pars" (n. 4 above), 17. On the Third Lateran Council and the reception and authority of conciliar canons, see Summerlin, "Reception and Authority." 
Finally, when Innocent III (d. 1216) convoked the Fourth Lateran Council in 1215, he may have had an idea of what impact this council would have, not least on pastoral care. ${ }^{41}$ The council is definitely the most renowned of all. It is also more explicit about almost everything, including episcopal elections, a subject that is brought up for discussion in cans. 23-26. In can. 23 it is stated "that a cathedral church or a church of the regular clergy is not to remain without a prelate for more than three months." If this limit is not observed, "those who ought to have made the election are to lose the power to elect for that time and it is to devolve upon the person who is recognized as the immediate superior." He shall, however, provide "the widowed church, with the advice of his chapter and of other prudent men, with a suitable person from the same church, or from another if a worthy candidate cannot be found in the former." ${ }^{\prime 2}$ In can. 24 it is established that a canonically valid election can be achieved through different modes of procedure, namely, by balloting (later recognized as per scrutinium, whereby the person who receives the vote of all or of the greater or sounder part of the gathered congregation - uel maior uel sanior pars capituli consentit is elected), by delegating the choice to confidential persons (later recognized as per compromissum), or "as if by divine inspiration ["per inspirationem']." ${ }^{43}$ It is also

41 A letter from Innocent III to the archbishop of Sweden and his suffragan bishops, abbots, and priors in the ecclesiastical province of Uppsala has been preserved in the original at the Swedish National Archives (Riksarkivet) in Stockholm. It is the only extant original invitation to the Fourth Lateran Council in 1215, Dipl. Suec., no. 145, (19 April 1213) or Svenskt Diplomatariums huvudkartotek, no. 329, accessed 3 July 2015, http://sok.riksarkivet.se/sdhk. See also Dipl. Dan., I 5, no. 32; Reg. Norv., nos. 355-56. It has not been confirmed, but presumably the archbishop of Lund, Anders Suneson, attended the council in the company of two bishops from the Province of Nidaros, namely, Archbishop Guttorm of Nidaros and Bishop Nicholas of Sodor. See Dipl. Dan., I 5, no. 41, where Archbishop Anders is exhorted by the pope to be present at the council. In the reconstructed list of participants at the council, there is only a reference to an anonymous Danish bishop, namely, "episcopus de Datia." See Jakob Werner, "Nachlese aus Zürcher Handschriften, I.," Neues Archiv der Gesellschaft für ältere deutsche Geschichtskunde 31 (1906): 575-93 at 586; cf. Danmarks Riges Breve, I.5, 64n5 and 94n2 and Papal Intervention, below. On the participation from the Province of Nidaros, see Reg. Norv., nos. 384 and 414n1.

42 "Statuimus ut ultra tres menses cathedralis vel regularis ecclesia prelate non vacet, infra quos iusto impedimento cessante, si electio celebrata non fuerit, qui eligere debuerant, elegendi potestate careant ea vice ac ipsa eligendi potestas ad eum, qui proximo praeesse dignoscitur, devolvatur. Is vero ad quem devoluta fuerit potestas, Dominum habens prae oculis, non differat ultra tres menses cum capituli sui consilio et aliorum virorum prudentium, viduatam ecclesiam de persona idonea ipsius quidem ecclesiae vel alterius, si digna non reperiatur in illa, canonice ordinare, si canonicam voluerit effugere ultionem." Lateran IV (1215), can. 23, p. 246.

43 "Statuimus ut cum electio fuerit celebranda, praesentibus omnibus qui debent et volunt et possunt commode interesse, assumantur tres de collegio fide digni, qui secreto et singulatim voces cunctorum diligenter exquirant, et in scriptis redacta, mox publicent in communi, nullo prorsus appellationis obstaculo interiecto, ut is collatione adhibita eligatur, 
established in can. 25 that "being elected through abuse of the secular power" is "against canonical freedom." 44 In can. 26 it is laid down that a proper confirmation of the election is required..$^{45}$ For the first time, it is explicitly said that a chapter should be involved in the election of a bishop. At the same time, the formulation "those who ought to have made the election" may still involve a wider circle than just the local chapter. Secular interference, however, is explicitly prohibited. ${ }^{46}$

The concept of "canonical" was evidently important to the Conciliar Fathers, but its meaning is not always clear. An election undertaken by clergy and people, per clerum et populum, was certainly regarded as canonical for a long time, but then this concept fades from view. When did it cease to matter? And how should one identify the men behind the terms "clergy" and "people" respectively? The content and reach of these words seems to change over time.

Scholars sometimes use the concept of "canonical" to refer exclusively to elections performed "without lay interference." In view of what has been discussed above, such a usage must be regarded as deceptive since it applies only from the mid-twelfth century onwards. Of course, bishops were canonically elected and appointed before this time, too. In order to avoid anachronism, "canonical" in the context of episcopal elections should be interpreted simply as "in accordance with the then ecclesiastical legislation." 47

According to Bernhard Schimmelpfennig, "from the 1130s onwards the way was prepared, at least in legal theory, for the limitation of the electorate to the

in quem omnes vel maior vel sanior pars capituli consentit; vel saltem eligendi potestas aliquibus viris idoneis committatur, qui vice omnium ecclesiae viduatae provideant de pastore; aliter electio facta non valeat, nisi forte communiter esset ab omnibus quasi per inspirationem divinam absque vitio celebrata." Lateran IV (1215), can. 24, p. 246. For more specific information on the method of election by the sanior pars, see Schimmelpfennig, "The Principle of the Sanior Pars," 16-17, who argues that this mode of election was influenced by the instructions for abbatial elections in the Rule of St. Benedict.

44 "Quisquis electioni de se factae per saecularis potestatis abusum consentire praesumpserit contra canonicam libertatem, et electionis commodo careat et ineligibilis fiat, nec absque dispensatione possit ad aliquam elegi dignitatem." Lateran IV (1215), can. 25, p. 247.

45 Lateran IV (1215), can. 26, p. 247. Here the Conciliar Fathers recall a previous practice of confirmation that is no longer valid: "For, if confirmation was granted in advance when everything was not in order, then not only would the person improperly promoted have to be rejected but also the author of the improper promotion would have been punished." ("Quia si secus fuerit incaute praesumptum, non solum deiciendus est indigne promotus, verum etiam indigne promovens puniendus.")

46 Schimmelpfennig, "The Principle of the Sanior Pars," 17-18.

47 On the concept of "canonical" in relation to elections, see Paul Schmid, Der Begriff der kanonischen Wahl in den Anfängen des Investiturstreits (Stuttgart, 1926); on Gratian's development of the concept of canonicity in the context of episcopal elections, see Joubert, "L'élection épiscopale" (n. 36 above). 
cathedral chapter and an increased importance for the sanior pars." 48 Indeed, the conciliar decrees presuppose the existence of cathedral chapters already in the late 1130 s even though not all cathedrals may have had an organized chapter. It is true that cathedral chapters, meaning corporate bodies each with its own regulations and leader, did exist from as early as the fifth century, albeit with great geographical variations. ${ }^{49}$ In the Carolingian Empire the institution became relatively permanent at the cathedral churches, and the Rule of Aachen was established in 816 as its general rule. ${ }^{50}$ But there are no indications that a cathedral had to have a regulated chapter. Also worth noting is the fact that no legal obligations devolved upon these early capitular institutions. Their main functions were to provide for the cathedral liturgy and to manage the cathedral school, functions that were retained throughout the Middle Ages but to which others were gradually added. Playing a primary role in the election of bishops was such an added duty. ${ }^{51}$ The decrees of the Second Lateran Council reveal that already in 1139 a new understanding of the nature and functions of cathedral chapters was presupposed. With the conciliar decrees from 1123 to 1215, a certain standard was achieved. This standard was meant to apply also to the younger ecclesiastical provinces, such as the Danish church and its bishops. To the question of whether it did so in fact, and not merely in theory, we now turn. ${ }^{52}$

Episcopal appointments in DenMark until 1225

\section{The Danish Setting}

Until 1103/4, the kingdom of Denmark was ecclesiastically subject to the archdiocese of Hamburg-Bremen and its archbishops. With few exceptions, it was also the German archbishops that provided the Danish kingdom with its bishops.

48 On the method of election by the sanior pars, see Schimmelpfennig, "The Principle of the Sanior Pars," 17.

49 Philipp Schneider, Die bischöflichen Domkapitel, ihre Entwicklung und rechtliche Stellung im Organismus der Kirche, new ed. (Mainz, 1892); Henri Leclercq, "Chapitre des cathédrales," in DACL 3 (1913), cols. 495-507; Charles Dereine, "Chanoines," in DHGE 12 (1953), cols. 353-58; Benson, The Bishop Elect (n. 8 above), 27; H.-J. Becker and J. Dubois, "Kapitel," in Lexikon des Mittelalters 5 :cols. 38-41.

50 The Rule of Aachen (816) has been translated into Swedish by Anna Minara Ciardi (2003) and into English by Jerome Bertram (2005).

51 Cf. Anna Minara Ciardi, "Saints and Cathedral Culture in Scandinavia c. 1000-c. $1200, "$ in Saints and Their Lives on the Periphery: Veneration of Saints in Scandinavia and Eastern Europe (c. 1000-1200), ed. Haki Antonsson and Ildar Garipzanov, Cursor mundi 9 (Turnhout, 2010), 44-45.

52 Cf. Pixton, The German Episcopacy (n. 4 above), esp. 184-318; and Harvey, Episcopal Appointments (n. 7 above). 
In his article from 2004, "Elusive Bishops," Michael H. Gelting presents both the traditional view and his own hypotheses on how the Danish episcopate formed from the time of the Christianization of Denmark in the late tenth century until circa 1059. Gelting argues, mainly on the basis of Adam of Bremen's chronicle Gesta Hammaburgensis ecclesiae pontificum, that the period was characterized primarily by three things: first, a college of bishops that was controlled (ecclesiastically, not politically) from Germany, many of whom did not even reside in Denmark; ${ }^{53}$ second, the conflicts of loyalty to which this mostly foreign college often led; and, third, a continuous and more or less explicit royal ambition to establish an independent ecclesiastical province in the kingdom of Denmark, an ambition that had been evident since the very beginning of the eleventh century. ${ }^{54}$ According to Gelting, a decisive step was taken when King Sven Estridson reorganized three Danish episcopal sees into nine. To the bishoprics Ribe, Slesvig (both in Jutland), and Odense (in Funen) that were all established in the tenth century, he added Aarhus, Viborg, Børglum (Jutland), Roskilde (Sealand), Lund, and Dalby (Scania). By doing so, he fulfilled the endeavors of his predecessors and especially his grandfather Cnut the Great (d. 1016). An apt ecclesiastical organization was a prerequisite for obtaining the final goal: the creation of a Danish ecclesiastical province independent of the power-seeking archbishops of Hamburg-Bremen and subject to Rome alone. ${ }^{55}$ From then on, the number of bishops appointed by the Danes and their king increased. ${ }^{56}$ In 1103/ 4, thirty years after Sven's death, his goals were accomplished: an ecclesiastical province was established in Denmark, and Lund became its archiepiscopal see.

From the mid-eleventh century onwards - that is, as soon as the Danish bishops became permanently resident - the institution of cathedral chapters began to evolve in Denmark. Chapters with prebends were established in Roskilde in the 1070s, in Lund and Odense in the 1080s, and in Ribe in the 1140s at the latest. The last Danish cathedral chapter to receive a firm organization with prebends was that of Aarhus in the late twelfth century. In the beginning of the period here at issue, the main function of the capitular institution was liturgical. Along the way more functions were added, and, by the end of the first quarter of the thirteenth century, one of their main functions was legal, namely, to act as

53 Adam of Bremen, Gesta Hammaburgensis ecclesiae pontificum; Gelting, "Elusive Bishops" (n. 3 above) 169-87.

54 Gelting, "Elusive Bishops," 175-87.

55 For an overview of the Christianization of Denmark and later developments in the period at issue, see idem, "The Kingdom of Denmark" (n. 3 above), 73-120 at 73-95. On the Danish bishops in the earlier period, see also idem, "Elusive Bishops."

56 On the Danish series episcoporum until the 1210s, see Odilo Engels, Tore Nyberg, and Stefan Weinfurter, eds., Series episcoporum ecclesiae catholicae occidentalis ab initio usque ad annum MCXCVIII, 6th ser., Britannia, Scotia et Hibernia, Scandinavia, T. 2, Archiepiscopatus Lundensis (Stuttgart, 1992). 
electoral body at episcopal elections. ${ }^{57}$ In the context of the aforementioned legal developments, it is interesting to examine whether and to what extent the universal legal achievements with regard to episcopal appointments affected (or did not affect) an ecclesiastical province on the periphery of the Roman Church.

\section{Sources}

What sources can provide us with information about episcopal appointments in Denmark during this period of almost 200 years? And what can be established about such appointments in a period of legal transition?

The sources I have found most relevant for my purpose are: the customary of the cathedral chapter in Lund, called the Consuetudines Lundenses, from circa 1120; sections from three indigenous chronicles that were composed soon after the events they describe: the Roskilde Chronicle, the Gesta Danorum by Saxo Grammaticus, and the Ribe Chronicle; and a few papal letters from the period $1176 / 77-1225 .{ }^{58}$

\section{Consuetudines Lundenses}

Of particular interest are the Consuetudines Lundenses, which constitute the customary used by the cathedral chapter at St. Lawrence's in Lund from 1123 at the latest. ${ }^{59}$ In 1908, the Danish scholar Ellen Jørgensen identified the sources of the customary: it was modeled on sources from Cluny and, in particular,

57 See Ciardi, "Saints and Cathedral Culture," esp. 41 and 46.

58 Some information about an earlier period is given in Adam of Bremen, Gesta Hammaburgensis ecclesiae pontificum, lib. IV, which was completed in $1072 \times 76$. On the dating of Adam of Bremen's work and his depiction of the ecclesiastical developments of the North, see, e.g., Henrik Janson, "Adam of Bremen and the Conversion of Scandinavia," in Christianizing Peoples and Converting Individuals, ed. Guyda Armstrong and Ian N. Wood (Turnhout, 2000), 83-88; and Erik Gunnar Niblaeus, "German Influence on Religious Practice in Scandinavia c. 1050-1150" (PhD diss., King's College, London, 2010), 106-51.

59 The original is preserved in the codex Necrologium Lundense, Lund, Lund University Library (LUB), MS 6, fols. 105r-106r. Accessible also at Alvin: portal för kulturarvssamlingar, accessed 15 December 2015, http:/urn.kb.se/resolve?urn=urn:nbn:se:alvin:portal:record14714. As I have pointed out elsewhere, there are weighty arguments for assuming that the Consuetudines Lundenses - or Consuetudines canonica, as they are labeled in the original manuscript - were adopted as customary or additional statutes in addition to the Rule of Aachen by the cathedral chapter of Lund in 1123 at the latest; see Anna Minara Ciardi, "Consuetudines Lundenses," in Medieval Nordic Literature in Latin: A Website of Authors and Anonymous Works c. 1100-1530, ed. Stephan Borgehammar et al. (Bergen, 2012), accessed 10 November 2015, https://wiki.uib.no/medieval/index.php/Consuetudines_Lundenses. For more specific information on the dating, see Anna Minara Ciardi, "När tog lundakanikernas Consuetudines egentligen i bruk? Reflektioner kring traditionsförmedling och texttradering i 1120-talets Lund [with a Summary in English]," Kyrkohistorisk Arsskrift 104 (2004): 11-21. 
on the so-called Consuetudines Marbacenses from the Augustinian monastery in Marbach, Alsace. Both places were renowned as centers of reform in the Gregorian reform movement. By establishing the provenance of the original source, it was also possible for her to specify what parts of the younger redaction in Lund derived from other sources or were compiled in order to meet local needs and conditions. ${ }^{60}$ For more than a century, Scandinavian scholars have tried to date the Consuetudines Lundenses and establish when it was brought to Lund, edited, and made ready for use. A recent redating of the Consuetudines Marbacenses has made likely a transmission to and usage in Lund earlier than had previously been suggested. ${ }^{61}$

For the purpose of this article, it is significant to comment briefly on the Sitz im Leben of the model text and to share some observations on which parts were modified or added in order to serve the clerical community in Lund. The Augustinian monastery in Alsace was founded in 1089/90 in a place that was under the sway of the then-ongoing reform movement. The immediate contact with reformist centers like, for example, the congregations in St. Ruf in Avignon, St. Victor in Paris, and Cluny, certainly played a decisive part in the design of the Consuetudines Marbacenses and its later redactions. Yet the Marbach community belonged to the older Augustinian reformist tradition, ordo antiquus, rather than the younger ordo novus, which gained papal approval in the course of the twelfth century. ${ }^{62}$ According to Erik Buus, who in 1978 published a critical edition of

60 Ellen Jørgensen, "Fremmed Indflydelse under den Danske Kirkes tidligeste Udvikling," in Det Kongelige Danske videnskabers selskab, vol. 7, Historisk-filologiske skrifter, Afd. 2:1. (Copenhagen, 1908), 123-215. Jørgensen argued, however, that it was not possible to define more closely when, how, or why this text was adopted by the canons at St. Lawrence's in Lund: see eadem, "Fremmed Indflydelse," 137, 145-47.

61 For an overview of editions, translations, and previous scholarly research on the Consuetudines Lundenses, see Ciardi, "Consuetudines Lundenses." Josef Siegwart's dating of the Consuetudines Marbacenses to ca. 1122-24, published in 1965, indicated that the Consuetudines Lundenses could hardly have been copied and transmitted to Lund before the 1130s. See idem, "Einleitung," in Die Consuetudines des Augustiner-Chorherrenstiftes Marbach im Elsass (12. Jahrhundert), ed. idem, Spicilegium Friburgense 10 (Freiburg, 1965), 3-98 and esp. 263-70. In the early 1990s, however, Helmut Deutz established 1098 as the terminus ante quem of the oldest part of the Consuetudines Marbacenses. See Helmut Deutz, "Einleitung," in Consuetudines canonicorum regularium Rodenses: Die Lebensordnung des Regularkanonikerstiftes Klosterrath; Text erstellt von Stefan Weinfurter; übersetzt und eingeleitet von Helmut Deutz, Fontes Christiani 11 (Freiburg, 1993), 1:7-109 and esp. 11-12.

62 Cf. Ciardi, "Consuetudines Lundenses." On the Consuetudines Marbacenses and the Augustinian reform movement, see Siegwart, "Einleitung," 5-6, 29-30, and 71-74; Stefan Weinfurter, Salzburger Bistumsreform und Bishofspolitik im 12. Jahrhundert: Der Erzbishof Konrad I. von Salzburg (1106-1147) und die Regularkanoniker, Kölner historische Abhandlungen 24 (Cologne, 1975), 235-40; and idem, "Einleitung," in Consuetudines canonicorum regularium Springirsbacenses-Rodenses, ed. Stefan Weinfurter, CCM 48 (Turnhout, 1978), vi-xxxix and esp. $\mathrm{x}-\mathrm{xi}$. 
the Consuetudines Lundenses, the different conditions in Alsace and Lund affect both the composition and the understanding of the text: only the first 147 paragraphs out of the original 359 of the Marbach text were incorporated into the Consuetudines Lundenses; the name of St. Augustine is consistently left out in Lund since the canons at St. Lawrence's had another basic regula or rule, namely, the Rule of Aachen. ${ }^{63}$ Of major significance are the instructions for episcopal elections given in the Consuetudines Lundenses, chapter 16. This chapter corresponds to the chapter on the election of a provost in the Consuetudines Marbacenses, whereas in Lund the appointment of a provost is described in the following chapter. ${ }^{64}$

What, then, are the instructions for episcopal elections provided by the Consuetudines Lundenses, chapter 16 ?

[§81] When the Lord Bishop has died, we convoke the prelates from all our congregations and by their common counsel apply ourselves to the election. When they have gathered it behooves us all to fast for three days, so that we may receive right counsel from the Lord concerning the election. Thereafter we lay the charge of election upon twelve men of good sense ["sanioris consilii"] and agree among ourselves that, whomever these will choose, all of us will approve without debate. These twelve then spend the night before the election without sleep, devoting themselves to psalms and prayers. When the day dawns they are to have mass celebrated for them and are to enter the capitol with the others. There the lesson of Paul the Apostle to Timothy, If a man desire the office of a bishop [cf. 1 Tim. 3:1], is to be read.

[§ 82] After this it is once again asked whether anyone objects to the choice of these men. When all have answered no, the twelve go out to deliberate while the remainder stay in the capitol devoutly singing the Psalm, Give ear, you who rule Israel [cf. Ps. 80:1]. Returning quickly they announce their choice, and rejoicing and singing Te deum laudamus they take hold of the elect and lead him without delay, willingly or unwillingly, into the church.

[§ 83] There he is to be dressed in a cloak before the altar, but the pontificalia - I mean the ring and staff - he must himself take from the altar, after which he is placed on the episcopal throne. Then the abbots and

63 Erik Buus, "Indledning," in Consuetudines Lundenses: Statutter for kannikesamfundet $i$ Lund c. 1123, ed. Erik Buus (Copenhagen, 1978), 9-106 and esp. 42-43 and 85-96. The critical edition of Consuetudines Lundenses is found on pages 109-78. For more on the redaction of Consuetudines Lundenses, see Ciardi, "Consuetudines Lundenses."

64 The text and procedure described in chap. 17 is, however, without parallel in the Marbach text, which either points to an unidentified source or implies that the instruction was compiled specifically for the chapter in Lund. Cf. Buus, "Indledning," 41-45; Ciardi, "När tog lundakanikernas Consuetudines," 112-13; and eadem, "Consuetudines Lundenses." 
provosts shall approach him and first bend their knees; then, one by one, they shall kiss him and place their hands in his and promise obedience. ${ }^{65}$

What observations can be made with respect to this electoral procedure? A first observation is that we are dealing with a clearly defined electoral body (§81): at the death of the bishop, the chapter shall summon the prelates of their confraternal congregations, and together with them appoint twelve men who must be accepted by all, who will choose a candidate. ${ }^{66}$ It is further intimated that the candidate elected by the twelve has been approved of in advance, "whomever these will choose," and that the electus should accept the choice "willingly or unwillingly." A second observation concerns the electoral process itself: after having made their choice, the electors are assumed, or even implored, to return quickly (mox) to announce their choice. It seems as if no negotiation is required as long as all fulfill their respective duties; altogether, we here find a description of a quick and efficient procedure (§§81-82). A third observation concerns the "confirmation of the election and the liturgical setting" (§83): first, the newly elected shall be led "without delay, willingly or unwillingly, into the church," where he shall be dressed but "must himself take from the altar" the ring and the staff, which is the spiritual or pontifical investiture (pontificalia); ${ }^{67}$ second, and apparently still in the church, the abbots and provosts should welcome their new bishop

65 “[§81] Domino episcopo defuncto prelatos omnium nostrarum congregationum conuocamus et eorum communi consilio electioni uacamus. His congregatis placet omnibus triduanum ieiunium peragere, ut rectum electionis consilium a domino mereamur suscipere. Hanc tandem super duodecim sanioris consilii statuentes inter nos confirmamus, ut quemcunque isti elegerint, omnes sine disceptacione laudemus. Noctem igitur diem electionis precedentem hi duodecim psalmis et orationibus insistentes insomnem ducunt. Mane autem facto missam sibi celebrari faciant et cum ceteris capitolium intrent. Ibi legatur lectio Pauli apostoli ad Timotheum Si quis episcopatum desiderat. [§82] Post hęc iterum queritur, utrum aliquis ab electione eorum dissentiat. Quod cum omnes negauerint, aliis in capitolio remanentibus et psalmum Qui, regis Israel, intende, deuotissime canentibus, illi .xii. ad consilium exeunt. Mox reuertentes eligunt et electum gaudentes et Te deum laudamus canentes rapiunt re et in ecclesiam sine mora uelit nolit ducunt. [§83] Ibi coram altari cappa inuestiatur, pontificalia uero, anulum dico et uirgam, propria manu ab altari suscipiat, de hinc in cathedra episcopali collocatur. Tunc abbates et prepositi debent accedere genua primum flectentes et singillatim eum osculantes et manus manui eius dantes obedientiam promittere." Consuetudines Lundenses, chap. 16 ("De electione episcopi"), my translation.

66 On the institutions in confraternity with the cathedral chapter at St. Lawrence's, see "Series ecclesiarum qui fraternitatem Lundensi ecclesie habent cum allegatis," in Necrologium Lundense: Lunds domkyrkas nekrologium, ed. Lauritz Weibull, Monumenta Scaniae historica (Lund, 1923), 126-30; and idem, "Inledning," in ibid., v-cii at lxxi-lxxx. On instructions regarding the notice of a deceased member of the cathedral chapter and on the commemoration of a deceased brother by a confraternal institution, see Consuetudines Lundenses, chap. $34, \S 177$, and chap. 35 .

67 This form of investiture is sometimes labeled "Selbstinvestitur," and is known already from the pontificate of Pope Gregory VII. Around the year 1123, there are indications that 
and "promise him obedience." It is not clear how the rest of the gathered clergy should act or how the official (ecclesiastical) confirmation of the elections was to be performed or by whom. ${ }^{68} \mathrm{~A}$ fourth and final observation is that there is no reference to any lay influence at any stage of the process. We hear of no lay investiture (regalia) and not even the presence of a king or other lay persons. ${ }^{69}$

What do we know about the actual use of the Consuetudines Lundenses and the implementation of these surprisingly radical instructions? The answer must be: almost nothing. Although religious and legal regulations or instructions are formulated in order that they should be respected, it is often impossible to say to what extent they were, if at all. In addition, whereas some regulations concern regular actions, such as attending chapter or singing the canonical hours, episcopal elections were rare, making them seem like exceptional situations and thus more vulnerable to transgression. In fact, and as will be seen below, only two successions on the cathedra of Lund were made in the course of the twelfth century, namely in 1137/38 and in 1177 .

While it can safely be assumed that the Consuetudines Lundenses were compiled and put to use by 1123 at the latest, it is harder to draw any firm conclusions about how long they were observed. Some scholars have argued that the secularization of the chapter and thus its abandonment of a common, regular life in accordance with the Rule of Aachen and the Consuetudines Lundenses can be related to the inauguration of the cathedral church in $1145 .{ }^{70}$ Others have come to a similar conclusion by disregarding local conditions and referring to general developments in Europe at the time, namely, the fact that many older capitular foundations were made secular in the course of the twelfth century while new foundations in the latter part of the century were normally established as secular chapters. ${ }^{71}$ In my opinion, these arguments ex silentio carry little weight. There are reasons to suppose that the cathedral chapter in Lund remained regular at least until 1177, when Eskil (d. 1181/82) resigned as archbishop of

this mode of conduct was employed in several places, e.g., in Klosterrath. See Weinfurter, "Einleitung," xiii-xiv. Cf. Buus, "Indledning," 75.

68 Another papal letter, from Pope Innocent III, was sent in April 1213.

69 Cf. Buus, "Indledning," 65-75.

70 Cf. Weibull, "Inledning," lxxxvi; Ciardi, "När togs lundakanikernas Consuetudines," 15-16.

71 Cf. Kauko Pirinen et al., "Domkapitel," in Kulturhistoriskt lexikon för nordisk medeltid (Malmö, 1958), 2:cols. 185-201, and esp. cols. 186 and 192, where it is argued that the adoption of statutes or a customary such as the Consuetudines Lundenses indicate that the chapter was secular. The instructions of the Consuetudines Lundenses, chap. 5, on how to gather for the daily chapter as well as the disposition of the various texts of the codex itself, however, imply that the chapter remained regular also with the Consuetudines, albeit based on an older definition of "regular." With the Augustinians and Premonstratensians, for example, the label of "regular" came to indicate something else and a stricter conduct. See Buus, "Indledning," 34-37. 
Lund. He was renowned for being a reformist bishop of Roskilde and archbishop of Lund and an assiduous founder of monasteries throughout his province. Through his many personal contacts abroad, he was constantly updated on ecclesiastical and legal developments. I find it improbable that the regular cathedral chapter at St. Lawrence's was transformed into a secular one during his pontificate. ${ }^{72}$ It is true that a later martyrology and obituary known as the Liber daticus Lundensis vetustior was acquired by the canons in the early 1140s and that this contains no rule or customary. But both codices may have been concurrently in use for a time, or a separate codex with rules for the community may have existed. ${ }^{73}$

\section{Danish Chronicles}

Evidence from three indigenous chronicles will be used below. Together these mention several episcopal elections, and all three were composed so soon after the events they relate that their descriptions of the elections are unlikely to be colored by subsequent legal developments.

The oldest one is the Roskilde Chronicle, Chronicon Roskildense, from circa $1137 / 38$, the earliest Danish historical chronicle. Its anonymous author was probably a member of the clergy at the episcopal see of Roskilde. With regard to his knowledge of the local history there, it has been assumed that he was a canon of the cathedral chapter, having access to the capitular archives. The main source for the period until the 1070s is Adam of Bremen's Gesta, whereas the history thereafter has been considered "the main narrative source for Danish history until it ends in 1138." According to Gelting, the chronicle was written in immediate proximity to the events taking place after the death of archbishop Ascer of Lund in 1137, with the purpose of promoting bishop Eskil of Roskilde as

72 On archbishop Eskil of Lund, see Kaare Rübner Jørgensen, "Lundensis eccl. (Lund)," in Engels, Nyberg, and Weinfurter, eds., Series episcoporum ecclesiae (n. 55 above), 7-33 at 2028; and Ralf M. W. Stammberger, "Paris, Hildesheim and Dalby: The Migrations of Christian Culture; Scania in the Eleventh and Twelfth Centuries," in Locus Celebris: Dalby kyrka, kloster och gård, ed. Stephan Borgehammar and Jes Wienberg, Centrum för Danmarksstudier 28 (Gothenburg, 2012), 166-69.

73 Lund, Lund University Library (LUB), MS 7, or via Alvin: portal för kulturarvssamlingar, accessed 15 December 2015, http://urn.kb.se/resolve?urn=urn:nbn:se:alvin:portal:record13276. On this period in the history of the chapter and the relationship between Necrologium Lundense and the Liber daticus Lundensis vetustior, see various articles in the volume Mellan evighet och vardag: Lunds domkyrkas martyrologium Liber daticus vetustior (den äldre gåvoboken); studier och faksimilutgåva, ed. Eva Nilsson Nylander, Skrifter utgivna av Universitetsbiblioteket i Lund, n.f., 10 (Lund, 2014); esp. Stephan Borgehammar, "Liber daticus vetustior: ett martyrologium från 1100-talet," 105-30 at 121-22; and Gelting, "Forholdet mellem Liber daticus og Memoriale Fratrum," 131-50. 
his legitimate successor. ${ }^{74}$ Even so, the content of the chronicle does not only include the history of the Roskilde church and its bishops and chapter; it is a history of Denmark, although with specific attention to the situation in Roskilde. Given the author's affiliation with the local cathedral chapter, it is a bit odd that there is almost no information about that chapter's formation and undertakings.

The second chronicle is Saxo Grammaticus's history of the Danes, Gesta Danorum, finished about 1208. The author regularly uses the first person singular of himself but does not reveal his name in the text. Even so, he has been identified as Saxo, the secretary ("clericus") of one of the most powerful Danish archbishops, namely, Absalon (d. 1201). He was likely born in the 1160s and served as canon of the cathedral chapter at St. Lawrence's in Lund. His magnum opus was, according to Saxo himself, commissioned by Absalon, his employer and patron, and composed from the 1190 s to some time around 1208. It consists of sixteen libri, and, according to the editor Karsten Friis-Jensen, Saxo wrote the Gesta Danorum drawing from a wide range of sources, both in Latin (antique and medieval sources) and in the vernacular (Old Norse material), and

following a careful compositional model: the sixteen books are structured in halves and quarters in accordance with categories belonging to universal history, Books I-IV covering the heathen period before the birth of Christ, Books V-VIII the heathen period before the advent of Christianity to Scandinavia, Books IX-XII the missionary period and the period in which Christian Denmark belonged to the archdiocese of HamburgBremen, and finally Books XIII-XVI covering the years of the independent Danish archdiocese of Lund. ${ }^{75}$

The work is unique in a Scandinavian setting, both with regard to volume and content. Still, Saxo's eloquence along with a close affiliation to his master and the then-political situation mean that we should be cautious when it comes to using him as a reliable historical source.

The youngest of the three narrative sources from medieval Denmark here referred to is the Ribe Chronicle, the Cronica ecclesice Ripensis. It was probably composed in the pontificate of Bishop Tue of Ribe, circa 1225-30, by an

74 Idem, "Chronicon Roskildense," in Medieval Nordic Literature in Latin (n. 59 above), accessed 10 November 2015, https:/wikihost.uib.no/medieval/index.php/Chronicon_Roskildense. A Latin edition was published by Martin Clarentius Gertz in 1917-18; a Danish translation by Michael H. Gelting was published in 2002.

75 Karsten Friis-Jensen, "Saxo Grammaticus," in Medieval Nordic Literature in Latin, accessed 10 November 2015, https://wiki.uib.no/medieval/index.php/Saxo_Grammaticus; Karsten Friis-Jensen, "Introduction," in Saxo Grammaticus, Gesta Danorum: History of the Danes, xxix-lxxx at xxix-xxxvi. Friis-Jensen's edition is the tenth edition; the most recent translations were made by Peter Zeeberg (Danish, 2005) and Peter Fisher (English, 2015). 
anonymous author, perhaps a canon of the local chapter. Like the aforementioned sources, the Ribe Chronicle begins in the missionary era with the first foundation of a church there and St. Ansgar's mission in the ninth century. Unlike both the older chronicles, however, this is quite appropriate since Ribe was established as one of the first bishoprics in the kingdom of Denmark, and, in contrast to the others, the author "adheres strictly to matters of direct concern to the history of the see." Gelting writes: "From the foundation of the cathedral chapter in 1145 the chronicle becomes highly informative. This part of the chronicle seems to build mainly or even exclusively on documents in the capitular archives, most of them now lost." 76

\section{Papal Letters}

The papal letters here referred to were sent to Danish bishops during the period 1176/77-1224. The oldest one is from Pope Alexander III to archbishop Eskil of Lund in connection with his resignation in 1177. The original letter is not preserved, but part of Eskil's petition for resignation as well as the response of Alexander III was later incorporated in the Liber Extra as a case or exemplum. ${ }^{77} \mathrm{~A}$ second letter is ascribed to Pope Lucius III (d. 1185). It has not been preserved but is referenced in the Ribe Chronicle. ${ }^{78}$ From the hand of Pope Honorius III (d. 1227), five letters from the period 1217-24 are referenced. The first one is from 1217 and deals with the episcopal see of Roskilde, whereas there are four letters from 1224 in relation to the capitular election of Peder Sakseson in Lund. ${ }^{79}$ The letters of popes Alexander III and Honorius III are of special interest as they indicate an immediate intervention in connection with episcopal appointments; in addition, these letters both refer to the then-ecclesiastical legislation and intimate a papal self-consciousness in the legal area.

\section{Examples: Episcopal appointments in Denmark until 1225}

At the time of Sven Estridson's reorganization of the Danish church circa 1059, there were already bishops appointed for the three oldest sees, namely, Odense, Ribe, and Schleswig. According to Gelting, however, most of the bishops for

76 Michael H. Gelting, "Cronica ecclesiæ Ripensis," in Medieval Nordic Literature in Latin, accessed 10 November 2015, https:/wiki.uib.no/medieval/index.php/Cronica_ecclesiæ_Ripensis. A Latin edition was made by Ellen Jørgensen in 1933-35 and Danish translations by Helge Søgaard (1972-74) and Inge Skovgaard-Petersen (1981) respectively; see Gelting, "Cronica ecclesiæ Ripensis."

77 Dipl. Dan., I 3.1, no. 61 (undated); CIC, vol. 2, no. 61, and chap. 1, X, De renunciatione, I 9.

78 "Post hunc Homerus, episcopus Burglanensis, translatus est ad sedem Ripensem auctoritate Lucii papæ anno Domini MCLXXXVI." Cronica ecclesiae Ripensis, 30.

79 Dipl. Dan., I 5, no. 102; I 6, nos. 1-4. 
these sees had been titular bishops, meaning that they had had the title and dignity of bishop but had never resided in their respective dioceses. ${ }^{80}$ Bishop Henry of Lund, though, may have resided there since (probably) the mid$1040 \mathrm{~s}^{81}$ The majority of Danish bishops in this period were of German or English origin, for example, Vilhelm of Roskilde (d. 1073) and Egino of Dalby (d. 1072) from Germany, and Henry of Lund (d. 1066) from England. Some of them had been sent to Denmark by ecclesiastical leaders abroad while others were appointed by the king.

\section{Royal appointment}

Most episcopal appointments in the early part of the period under study seem to have been royal appointments. ${ }^{82}$ Thus, in 1073, King Sven substituted (subrogavit) his own chaplain, Sven the Norwegian, for the deceased Vilhelm as bishop of Roskilde. ${ }^{83}$ In 1124, King Niels likewise substituted (subrogavit) his son's chaplain, Peter, for the deceased Arnold as bishop of Roskilde. ${ }^{84}$ Our source, the Chronicon Roskildense, in both cases uses the verb subrogare, meaning to substitute for or "to cause to be chosen in place of another."

In 1134, civil war ravaged the kingdom. All of society was affected, including the Church, most of whose bishops were related to one of the rival parties. Three of the bishops - Peter of Roskilde, Thore of Ribe, and Ketil of Vestervig (Børglum) - were killed in the Battle of Fodevig, and Adelbjørn of Schleswig was mortally injured there. ${ }^{85}$ According to the Roskilde chronicler, Eskil (Roskilde), Nothold (Ribe), Self (Vestervig), and Iluge (Aarhus) were subsequently made bishops (efficitur episcopus) in the town of Schleswig, presumably by King Erik Emune (d. 1137) himself and without any involvement of the local clergy and people or any of the cathedral chapters concerned. His own chaplain Rike was made (constituitur) bishop of Schleswig as replacement for Adelbjørn. ${ }^{86}$

\footnotetext{
80 Adam of Bremen, Gesta Hammaburgensis ecclesiae pontificum, liber IV; Gelting, "Elusive Bishops" (n. 3 above), 169-87.

81 Gelting, "Elusive Bishops," 190-91.

82 Ibid., 96.

83 "Nec multo post Villelmus obijt, cui gloriosus rex Sveno equiuocum suum et capellanum subrogauit." Chronicon Roskildense, chap. IX, p. 23.

84 "Arnoldus uero sequenti anno post illam incepcionem bundonum obijt. Cui rex Nicholaus capellanum filij sui Magni, nomine Petrum, subrogauit." Chronicon Roskildense, chap. XIII, p. 26.

85 Chronicon Roskildense, chap. XV.

86 "Illic Eskillus in loco Petri Roskildensis efficitur episcopus, Notholdus in loco Thorici Ripis intruditur, Self Wendalensium in loco Ketilli subrogatur, Illugo Arusiensium post Ulkillum constituitur. Interea infidelis Adelbyorn, Sleswicensium episcopus, de uulnere supradicto moritur. Post quem Rico, capellanus Herici, constituitur." Chronicon Roskildense, chap. XVI, p. 30.
} 
We do not know how the appointment of the bishops of Ribe - Thore (d. 1134), Ascer (d. ca. 1142), and the ill-famed Radulph (d. 1171) — were undertaken, but again it may have been by royal appointment alone. ${ }^{87}$

Election "by clergy and people"?

In three cases, we hear of something that could be understood as episcopal appointments undertaken by or with the involvement of "clergy and people." According to the Roskilde chronicler, "together with all the clergy of Sealand [“cum omni clero Selandensis"], King Olav Hunger (d. 1095) enthroned Arnold as bishop." $" 88$

A more delicate matter was the election or appointment of archbishop Ascer's successor in 1137. Both the Roskilde chronicler and Saxo vividly describe the course of events, the lay interventions and the competitors, bishop Eskil of Roskilde and bishops Rike of Schleswig (d. 1139). According to the Roskilde chronicler, Rike "had been elected by the clergy and people of Scania ["electus a Scaniensi clero et populo"]" as archbishop of Lund, but through the interference of a lay person in Sealand, a certain Peder Bodilson, bishop Eskil was promoted and finally seized that position, whereas Rike agreed to accept the see of Roskilde. The Roskilde chronicler recalls how Rike took charge of Roskilde "despite the protests of the clergy and people [there]" ("clericis et laicis reclamantibus"). ${ }^{89}$ A somewhat different story is told by Saxo Grammaticus at least half a century

87 "Post quem Thuri in episcopum est promotus... . Post Thuri Nothel, post Nothel Ascerus [ante 1142] ecclesiam Ripensem rexit... . Mortuo Helia et sepulto iuxta sanctum Leofdanum factus est episcopus Radulphus Anglicus regis Woldemari primi cancellarius anno Domini 1152. Cuius consecratio per Eskillum archiepiscopum ad annos quatuor est suspensa propter crimina homicidii et apostatiae sibi imputata." Cronica ecclesiae Ripensis, 27-28.

88 "Cuius morte audita Olauus rex cum omni clero Selandensis ecclesie, licet doluit, Arnoldum tamen intronizauit." Chronicon Roskildense, chap. XI, p. 25.

89 "Eo tempore non mediocris lis inter Rukonem, Sleswicensem episcopum, et Eskillum, Roskildensem antistitem, de Lundensi archiepiscopatu orta est. Quod tamen certamen venerabilis Petrus, filius Botildis, suo sapienti consilio et sollerti discrecione sedauit, et eos hoc modo pacificauit, quatinus Eskillus archiepiscopatum optineret. Ruko, quamuis electus a Scaniensi clero et populo, tamen utens consilio predicti Petri et disturbacionem et werram deuitans, Roskildensem sibi episcopatum clericis et laicis reclamantibus usurpauit." Chronicon Roskildense, chap. XIX, p. 32. The turmoil that followed the death of archbishop Ascer of Lund in 1137, the aspirations of bishop Eskil, and lay involvement have been thoroughly examined by Michael H. Gelting, who also suggests new interpretations of how to understand the then-political and -ecclesiastical situation. See Michael H. Gelting, "Da Eskil ville være ærkebiskop af Roskilde: Roskildekrøniken, Liber daticus Lundensis og det danske ærkesædes ophævelse 1133-1138," in Ett annat 1100-tal. Individ, kollektiv och kulturella mönster i medeltidens Danmark, ed. Hanne Sanders, Peter Carelli, and Lars Hermanson, Centrum för Danmarksstudier 3 (Gothenburg, 2004), 181-229. 
later. Saxo recalls how "when it came to [Ascer's] replacement by a new archbishop of Lund, the king and people [of Scania] were divided in their support," and "the Scanians gave their approbation to Eskil" ("Scanienses Eskyllum suffragiis amplectuntur"). Still, they kept it to themselves out of fear for the king, Erik Emune (d. ?), who had long been an antagonist of Eskil (and Peder Bodilson) and thus preferred Rike. ${ }^{90}$ The king died shortly after, and his successor, Erik Lam (d. 1146), aimed at bringing the matter to an end by installing Rike as archbishop in Lund. At this point, however, the people of Scania were willing to take up arms against the king, causing him to retreat: "Giving Eskil permission, therefore, to change his see, he appointed Rike bishop of Sealand, conditional on the clergy's support ["mediantibus cleri suffragiis"]." "91

A third occasion where the influence of the people seems to have mattered in the context of an episcopal appointment is when Rike's successor in Schleswig was to be chosen in 1139. According to a document ascribed to King Erik Lam, a certain Hermann, canon in Lund and royal chancellor, had been "deprived of his episcopal see," that is, Schleswig, "due to turmoil and upheaval among the people there." Apparently, Hermann was preferred both by the king himself and by Archbishop Eskil. But instead a certain Occo was appointed and consecrated by Adalbero, the archbishop of Hamburg-Bremen, as a consequence of a brief suspension of Lund's archidiocesan status. ${ }^{92}$ The Danes, however, recognized Hermann as the legitimate electus; he is recalled as Hermann, bishop of Schleswig, in several documents from that period. ${ }^{93}$

\section{Papal intervention}

In four cases, we hear of episcopal appointment by papal intervention. The first one again involves archbishop Eskil of Lund, who, as we have seen, seized the archiepiscopal office in 1137 under circumstances that are far from clear. In 1177, after almost four decades as Danish bishop and archbishop and after two decades in conflict with the Danish king, Valdemar I (d. 1182), Eskil resigned his office and took the monastic habit in Clairvaux. According to the ecclesiastical

90 "De noui antistitis suffectione diuiduum regis ac populi suffragium fuit. Siquidem Scanienses ... Eskyllum ... suffragiis amplectuntur." Saxo Grammaticus, Gesta Danorum, XIV $1.11-12$, p. 980 .

91 "Eskylloque sedem mutare permisso Rykonem Sialandie presulem mediantibus cleri suffragiis creat." Saxo Grammaticus, Gesta Danorum, XIV 2.4, p. 150.

92 Dipl. Dan., I 2, no. 91; Christian Radtke, "Sliaswig (Schleswig/Haithabu)," in Engels, Nyberg, and Weinfurter, eds., Series episcoporum ecclesiae (n. 55 above), 109-11. Cf. Tore Nyberg, Monasticism in North-Western Europe, 800-1200 (Aldershot, 2000), 117 and 159160. On the temporary abolishment of Lund as an archdiocese, see Gelting, "The Kingdom of Denmark" (n. 3 above), 94-95.

93 Cf. Radtke, "Sliaswig," 110-11. 
law then in force, however, he was not allowed to resign from episcopal office. Eskil had petitioned Pope Alexander III for his resignation in 1176/77, and in his response the pope reprimands the aging Eskil for violating ecclesiastical law but permits his resignation under certain conditions, namely, that Eskil should instigate a process "with the counsel and consent of other religious and qualified men" in order to find a successor. ${ }^{94}$ According to Saxo, Eskil told King Valdemar of his plans in private, upon which the king immediately referred to the canonical regulations that both prohibited and disqualified him, a lay person, from intervening. Eskil then referred to the papal letter and his duty of finding his own successor and reminded the king that he, Eskil, was a papal legate. At the time of Eskil's resignation in the cathedral of St. Lawrence in Lund, the elderly archbishop, according to Saxo:

stated that he was transferring the power which the favor of Rome had conferred on him to those who had traditionally held the right of election; he preferred to yield up his own privilege spontaneously rather than trespass on that of others, and did not wish to give the appearance of stealing from the Church the freedom to exercise its customary prerogative, seeing that he had always been on the alert to preserve its sovereignty. ${ }^{95}$

Both king and clergy, however, the latter claiming to speak for the people (plebs), demanded to hear from Eskil his opinion as to who should succeed him. Finally, says Saxo, Eskil named Absalon (d. 1201), then bishop of Roskilde, and there was an outbreak of joyful turmoil in the cathedral. ${ }^{96}$

In the context of the topic at hand, some points in this account are of special interest: first, Eskil's resignation is approved, albeit conditionally, and he is allowed to appoint his own successor, provided that he first consult and receive the consent of other qualified persons; second, by mentioning "other religious and qualified men," the pope seems to require participation of a wider circle of men, perhaps even lay persons, in finding a candidate; third, according to Saxo, Eskil is well aware of "who had traditionally held the right of election." But

94 Dipl. Dan., I 3.1, no 61. On Eskil's resignation and the legal conditions, see Mia Münster-Swendsen, “Erkebiskoppens endeligt: Et bidrag til udlægningen af sagen omkring Eskils resignation i 1177," in Kyrklig rätt och kyrklig orätt: kyrkorättsliga perspektiv, Festskrift till professor Bertil Nilsson, ed. Martin Berntson and Anna Minara Ciardi, Bibliotheca theologiae practicae 97 (Skellefteå, 2016), 339-53. Münster-Swendsen argues that other contemporary sources indicate that Eskil's resignation was forced upon him by Alexander III.

95 "Ea perlecta potestatem, quam sibi indulgentia Romana detulerat, ad eos, quibus eligendi ius esse consuerit, transferre se dixit, quod ultro iure suo cedere quam alienum offendere malit, ne ecclesiam, pro cuius maiestate tuenda semper excubuerit, consueto libertatis beneficio fraudare uideretur." Saxo Grammaticus, Gesta Danorum, XIV 55.1-58.1 (citation in XIV.55.8, p. 1426).

96 On the announcement and its eventful aftermath, see ibid., XIV 55.9-17. 
who were these? A wider circle of viri religiosi as described in the Consuetudines Lundenses as well as the decrees of the Second Lateran Council and the papal letter to Eskil - or the local chapter alone? Considering the current state of development of the legislation about episcopal elections and Saxo's words about the active involvement of king, clergy, and (indirectly) plebs, we must presume that Eskil (at least in the mind of Saxo) was referring to the traditional formula of clerus et populus, whereby clerus at this time would mean primarily the cathedral chapter but also other religious, and populus would mean influential laymen whose opinion was known to, and taken into consideration by, both king and chapter, the primary spokesmen on this occasion.

A second case is when Pope Lucius III confirmed the translation of bishop Omer of Børglum to Ribe. The chronicler claims that this happened in the year 1186, but that must be a mistake as Lucius III died in $1185 .{ }^{97}$ This may be seen as an early case of direct papal intervention in an episcopal appointment. ${ }^{98}$

A third intervention occurred in 1217, when Pope Honorius III granted a prolongation, originally given by Innocent III, of archbishop Anders Suneson's (d. 1228, bishop 1202-23/24) authority over the diocese of Roskilde, enabling the latter to appoint his nephew, a certain "magister .P.[eder Jakobson]," as bishop of Roskilde. ${ }^{99}$ In distinction to Saxo Grammaticus's account of Eskil's final speech and reference to "those who had traditionally held the right of election," we hear of no involvement of the powerful cathedral chapter of St. Trinitatis in Roskilde. Again, this may be seen as an example of how papal intervention increasingly could override established customs and regulations.

\footnotetext{
97 "Post hunc Homerus, episcopus Burglanensis, translatus est ad sedem Ripensem auctoritate Lucii papæ anno Domini MCLXXXVI." Cronica ecclesiae Ripensis, 30.

98 On the emergence of papal intervention as the normal form of episcopal appointment in the Middle Ages, see further Georg von Below, Die Entstehung des ausschliesslichen Wahlrechts der Domkapitel mit besonderer Rücksicht auf Deutschland (Leipzig, 1883); and, most recently, Harvey, Episcopal Appointments (n. 7 above), 129-85.

99 "Sane dudum cum esses apud sedem apostolicam constitutus bone memorie .I. papa predecessor noster fraternitati tue interuenientibus nobis indulsit. ut super facto Roskildensis ecclesie ad quam dilectus filius magister.P. nepos tuus uita et scientia sicut dicitur commendandus. superna est prouisione uocatus. presertim cum utilis sit eidem temporalium et spiritualium consideratione pensata / disponeres. quod honestati ecclesie ac saluti dicti magistri expedire uideres / consideratis diligenter circumstantiis temporum et locorum... . Nos igitur uolentes personam tuam quantum cum deo possumus honorare utpote qui te habundatiori diligimus caritate. discretioni tue auctoritate presentium indulgemus ut circa factum Roskildensis ecclesie ac sepefati magistri liceat tibi disponere quod prouide uideris disponendum." Dipl. Dan., I 5, no. 102. According to the letter, the pope recalled that the Danish archbishop had visited Rome, which may be an indication that Anders Suneson was present at the Fourth Lateran Council; see Werner, "Nachlese" (n. 41 above), 586. Cf. Per Bjørn Halvorsen, Dominikus: En europeers liv på 1200-tallet (Oslo, 2000), 115-18, and n. 41 above; cf. Episcopal Appointments, Ecclesiastical Law, and Legal Proceedings 1123-1215, above.
} 
At the resignation of the frail Anders Suneson in 1223/24, the cathedral chapter of Lund elected its provost Peder Sakseson as bishop. Even if much was done according to protocol and in line with the decrees from the Lateran councils, especially the Fourth - the election was undertaken within three months and by the cathedral clergy or chapter of Lund - Pope Honorius III declared the election null and void. In a letter from January 1224, the pontiff recounted his reasons, namely, incorrect procedure (the different parts of the voting process were not properly separated) and incorrect protocol (the choice was notified prematurely to the elected candidate). ${ }^{100}$ Peder Sakseson was instead appointed archbishop of Lund by papal provision, "in order that the Lord's flock should not lack the care of its shepherd for too long." 101 This papal intervention should, in my opinion, be understood as in full accordance with the decrees of the Fourth Lateran Council, while again indicating a new state of affairs in which episcopal elections could no more be a local affair but were always subject to papal scrutiny and in which bishops were increasingly named by the pope himself. ${ }^{102}$

\section{Capitular elections}

Somewhat surprisingly, the recorded number of purely capitular elections during the period is extremely small, despite the existence of the explicit and then very modern instructions of the Consuetudines Lundenses and despite the current trends in the development of ecclesiastical law. Even if we do not know about the exact electoral procedure, it is probable that the election of bishop Tue of Ribe in 1215 involved the local chapter. According to the Ribe chronicler, "the archdeacon Tue succeeded Olaf in 1215. He was the first to be elected from the chapter, but contrary to the king's will."103 Even so, the election of Tue seems to have been rather uncomplicated, whereas the aforementioned election of Peder Sakseson in 1224 caused papal intervention.

\footnotetext{
100 "Electo Lundensi. Cum post petitam instanter et demum obtentam uenerabilis fratris nostri ... quondam Lundensis archiepiscopi cessionem uota canonicorum Lundensium in te tunc ipsorum prepositum concorditer conuenissent / quia tandem examinato sicut decuit processu electionis tue inuenimus eam post publicationem consensuum et collationis tractatum aliquamdiu fuisse protractam assensumque tuum priusquam electus fueris requisitum; electionem eandem ex ipsius dumtaxat inordinato processu iustitia cassauimus exigente." Dipl. Suec, no. 221; Dipl. Dan. I 6, nos. 1-4 (citation in no. 1). On the procedure, see Danmarks Riges Breve, I 6, p. 2.

101 "Verum ne gregi Dominico diu deesset cura pastoris cum tam predictum." Dipl. Dan. I 6, no. 1 .

102 Lateran IV (1215), can. 24 and 26.

103 "Cui [Olauus] successit archidyaconus Tuuo anno Domini MCCXV. Hic primus de capitulo fuit electus, sed rege inuito." Cronica ecclesiae Ripensis, 31.
} 


\section{Reflections}

The first part of this essay gave an overview of the development of episcopal appointments, primarily in the West, until 1215, with special reference to the formula "by clergy and people" ("per clerum et populum"). The second part was dedicated to episcopal appointments in the kingdom of Denmark (ca. 1059-ca. 1225) as described in some of the indigenous and contemporary sources. This final part aims at stating some conclusions, first, about the development of procedures for episcopal appointments in general and specifically in Denmark and, second, about the development of canon law in relation to what I call cathedral culture.

It is evident that the concept "by clergy and people" already in the early Church reflected a desire to legitimate and validate the process and candidate, the electus. Only a lawfully appointed person could fulfill the requirements of and demands on a bishop, who was the representative of Christ himself. Therefore, the appointment had to be "canonical," that is, in accordance with ecclesiastical tradition and legislation. In the oldest sources, we hear of election "by clergy and people" as a method and practice that would reflect and fulfill these requirements. Representatives from the local Christian community, ordained and lay members alike, should be involved in the electoral process, but no precise information about the numbers or ranks of the participants is given. Other sources, like the decrees from the First Council of Nicaea (325), established the involvement of the college of bishops at a decisive moment in the process. This expresses a desire for the highest authority in the Church to wield influence over episcopal appointments even though lay participation may have been accepted at some point in the procedure. The decree of Nicaea was repeated later, at the Fourth Council of Constantinople (869-70). As regards elections "by clergy and people," the formula seems to have worked well as long as no party exceeded their authority in the process. In fact, election "by clergy and people" seems to have been an abiding ideal at least until the first decades of the twelfth century. It is evident that the concept was in itself useful, since it permitted some variation. Certainly, the key figures varied: at times the initiative may have lain with representatives of the clergy, at other times with lay participants. As long as both parties were consulted and an electoral process was undertaken, however, and no violence was done, there seems to have been no reason to call the outcome of the process into question. In short, the legal language ("per clerum et populum") and form (election) were upheld, but their practical application varied over time and from place to place. Until a certain point in time, "by clergy and people" was considered to be unassailable, the ideal.

The reformers of the eleventh century initially saw the benefits of preserving the concept in both language and form as it was established since time immemorial and had proved able to survive even in times of conflict over lay interference and 
what they considered as ecclesiastical decline. Gradually, however, "by clergy and people" became an obsolete ideal. ${ }^{104}$ This does not imply that the reformers considered their predecessors to have been in error or previous elections and appointments to have been invalid. Neither does it entail that the then-prevalent situation as such, with controversies over lay influence and investiture, was the sole determining factor. In my opinion, there are strong indications that the abandonment of "by clergy and people" had more to do with the aspirations of the papacy, which became manifest not only in the demand for "free elections" but also with the summoning of councils and the universal codification of ecclesiastical law.

There is a clear connection between language, ecclesiastical lawmaking, and practice. In many cases - for example, the cult of saints or certain liturgical or theological concepts or doctrines within the Roman Church - one may get the impression that ecclesiastical lawmaking rather confirmed an established practice than invented something new: by officially confirming and ratifying an established practice, the ecclesiastical authorities made it "canonical," meaning it was both approved of and valid. In ages of reform, however, it seems as if the language and the law anticipate the practice, for example, with regard to episcopal elections from the twelfth century and onwards. At the end of the period here examined, episcopal appointments undertaken or referred to by the formula per clerum et populum were no longer considered a guarantee of a canonical election but became, in legal terms, rather a reminiscence of the past. Despite a rather long period of transition before the new legal decrees were fully observed, not only was the legal procedure altered but so also was the concept of "canonical." Richard H. Helmholz summarizes it thus:

It was in the classical canon law that these reforms took definitive shape. The law of episcopal elections that was developed was also new law for the most part. Though ancient building blocks were used, the edifice eventually constructed would have looked quite unfamiliar to earlier Christians. This is not an area of the law ... where the Corpus iuris canonici simply enshrined, elaborated, and made binding rules that had been inherited from the earliest days of the church's history. ${ }^{105}$

Clearly, it is extremely hard to pinpoint a date when new or, for that matter, revitalized legal procedures were fully implemented. Rather, it is evident that the legal impetus of reduced lay influence on ecclesiastical elections and appointments

104 The question of lay participation in canonical elections was revived by the conciliarists of the fifteenth century. See Alexander Russell, "Popular Authority in Conciliar and Canonistic Thought: The Case of Elections," Revue de l'histoire des religions 231 (2014): 313-40.

105 Helmholz, The Spirit of Classical Canon Law (n. 2 above), 34. 
prospered simultaneously with, on the one hand, codification of ecclesiastical law and, on the other hand, the founding and formation of cathedral chapters as legal agents. ${ }^{106}$

Turning to the situation in Denmark in this period, we can make the following observations: in the sources referred to, there are indications that the formula "by clergy and people" is in these contexts synonymous with "canonical" - even after the introduction of both new decrees and regulations, such as the Consuetudines Lundenses, and the establishment of local cathedral chapters. In the case of Arnold's election in the $1080 \mathrm{~s}$, the Roskilde chronicler may have used a formula known to him in order to validate the appointment, meaning to show that things were properly done in Denmark at this point, without knowing exactly how things were carried out almost fifty years before the time of writing. In my opinion, royal appointment is more probable for the 1080 s than a proper election, even "by clergy and people." The same author is probably better informed when he describes the wrangling over the archiepiscopal see of Lund in 1137. Even if he is alleged to be contemporary with the turmoil in those days, his description of the appointment(s) in 1137 is hard to comprehend: at the time, full-fledged cathedral chapters existed in both Roskilde and Lund, but the chronicler does not involve them in the process(es) — or even refer to them. Why? According to him, the "clergy and people" initially took an active part in the appointment of archbishop Ascer's successor in favor of Rike; the outcome, however, with Eskil of Roskilde as the next Danish archbishop, is credited to a single lay person: Peter Bodilson. ${ }^{107}$ Saxo Grammaticus also describes a popular influence on the election, but in his description, "the clergy and people of Scania" gave their support to Eskil, not Rike. Neither mentions a process remotely resembling that laid down in the Consuetudines Lundenses. In sum, it is hard to draw any certain conclusions about the modes of episcopal appointment in Denmark in this period. Perhaps we would not have been told how a certain election was conducted or appointment made unless it was in the interest of the informant to account for it. With a few exceptions, namely, regarding the elections of 1137 and 1177 respectively, the authors were not interested in giving detailed descriptions of legal matters - that is, how the episcopal appointments were conducted or by whom; their primary focus seems to have been personal matters, namely, to account for the history of their own church and to establish its series episcoporum.

It seems as if most of the episcopal appointments in Denmark were performed by the king himself at least until the 1130s. It is true that royal support apparently was a necessary tool in safeguarding the new religion and its institutions. This may also be the reason why Rome and its reformers, despite their fervor,

106 Cf. Pixton, The German Episcopacy (n. 4 above), esp. 460-76.

107 According to Gelting, "Elusive Bishops" (n. 3 above), 96, the election in 1137 should be considered to be "canonical." 
did not interfere in Denmark, even in cases of direct lay appointments. At the same time, the Danish setting seems to have been fully in step with the thencurrent political and legal developments: the codification of a universal ecclesiastical law and the growing strength of the papacy both affect Denmark in obvious ways. At the beginning of the period there is no strong papacy, no common ecclesiastical law, and local anchoring is vital; at the end of the period, the situation is totally different: ideas of reform have been introduced, and the papacy is both aware of and actively intervening in the Danish situation. The Consuetudines Lundenses of 1123, which lay down a procedure for "free" episcopal elections performed without lay interference, together with the conciliar decrees of the Lateran councils, are examples of how legal texts can be signals of something new and different, something the secular rulers eventually will have to respect. Still, according to the extant sources, only two episcopal elections were likely performed by cathedral chapters in the period under consideration, namely, the election of Tue of Ribe (1215) and the overturned but later ratified election of Peder Sakseson in Lund (1225) - elections that took place a century after the Consuetudines Lundenses had presented the ideal of such elections being governed by the chapter.

In another context, I have argued that the concept of cathedral culture would help us to bring into focus a phenomenon that was influential in the Middle Ages but has been rather neglected by modern scholarship. ${ }^{108}$ The culture that evolved in and around the cathedral church was closely connected to the person of the diocesan bishop. This milieu was the center of another level of ecclesiastical organization that stabilized during the period under consideration here: the parochial organization. The power wielded at the cathedral church, the life lived there, and the rites performed served as an exemplar for the rest of the diocese. In addition, episcopal and cathedral culture played a decisive part in the consolidation of the newly Christianized societies in the north.

Cathedral culture has many components. Most are connected with the cathedral chapter, which performed the daily liturgy in the cathedral, assisted and advised the bishop, acted as guardians and executors of ecclesiastical law, educated the parochial clergy, undertook pastoral work in the diocese, and functioned as guardians of saints' shrines and other holy objects. This created a culture centered on the cathedral that probably had a greater impact than monastic culture upon the laity. An important function of this culture was to transmit and adapt the universal traditions of the Church to the local context.

The adoption of the Consuetudines Lundenses in the 1120s indicates that the cathedral chapter in Lund was up-to-date with the reformists' agenda and even

108 Anna Minara Ciardi, "On the Formation of Cathedral Chapters and Cathedral Culture: Lund, Denmark, and Scandinavia, c. 1060-1225" (PhD diss., Lund, 2016). 
anticipated ecclesiastical law with regard to episcopal appointments by election without lay interference. Yet, with a few exceptions, the narrative sources recall an older, traditional method of episcopal appointments where lay influence is taken for granted. In my opinion, the developments in Denmark correspond well with how ecclesiastical legislation and its implementation developed in general. If the prospect of flexibility with regard to episcopal appointments in Denmark was realistic until the beginning of the thirteenth century, the Danish church definitely kept up with ecclesiastical legislation after 1215, both in theory and in practice.

Cathedral chapters were established at all episcopal sees in Denmark by the 1190 s and, with them, cathedral culture. In the early period, however, in Denmark as elsewhere, the primary function of these chapters was not to legislate or to exercise jurisdiction but to be in charge of and perform the liturgy of the cathedral and to train young men for the priesthood. In my opinion, it is rather obvious that even though the institution of cathedral chapters existed from an early date, long before there was a universal and codified legislation, there was a strong reciprocal relationship between the institution and legal developments in the eleventh and twelfth centuries: on the one hand, the reforming fathers seem to have relied on cathedral chapters as institutions able to support their aspirations for legal and moral reform; on the other hand, the character of the cathedral chapters was altered as their new, legal functions were gradually added and made more specific. Hence, cathedral culture seems to have both prompted and been nourished by ecclesiastical legislation and reform. And, as time passed, the cathedral clergy certainly became more and more the center of attention when the local leaders of a reformed church were to be appointed.

The concept of cathedral culture certainly facilitates our understanding of a situation where many cathedral chapters in the course of the twelfth century became secular. In fact, "secular" was by this time used to label those capitular institutions that did not follow a monastic way of life. Already at that time, people conceptualized some sort of dynamism between monastic culture and cathedral culture, albeit without recognizing that cathedral culture had a positive identity of its own. By considering cathedral culture and monastic culture as two distinct phenomena composed of several elements (liturgy, law, economy, education, etc.), it becomes possible to examine and describe the collaboration and tension between the two in a more unprejudiced and dynamic way than has hitherto been customary. In this article, however, my purpose is only to comment upon certain legal aspects of this relationship.

Initially, the Gregorian reform movement promoted a "monasticization" of clerical communities of various kinds, which gave rise to a movement of reformed canons, later recognized as Austin canons, and eventually manifested in the Premonstratensian and Augustinian orders. Around the year 1100, many 
communities of cathedral clergy were thus "monasticized."109 This occurred also in Lund and is observable in the customary, the Consuetudines Lundenses: on the one hand, the instructions in chapter 5 for the daily chapter gathering (§§28-30) show that non-monastic traditions were being preserved, as the proceedings follow the Rule of Chrodegang rather than the Consuetudines Marbacenses, which were meant for reformed canons and follow the monastic tradition; ${ }^{110}$ on the other hand, the radical instructions for episcopal elections found in the Consuetudines Lundenses, chapter 16, originate from the Marbach text and its instructions for the election of a provost in a monastic community. These circumstances reflect how the reform movement at the beginning of the twelfth century aspired to reform the Church through ideals derived from monastic culture and life and thus how a mingling of cathedral and monastic culture took place.

In the course of the century, however, the reform work took another direction: the monastic ideal ceased to be an impetus for organizational change and was replaced by elaborated administrative and legal control structures. ${ }^{111}$ The alterations in instructions for episcopal elections throughout the century are evidence of such development. As late as 1177, archbishop Eskil was enjoined by the pope to consult certain viri religiosi in the process of appointing his successor. But, at the same time, if not earlier, the Consuetudines Lundenses, with their instructions about gathering prelates from confraternal institutions for the election of a new bishop, became obsolete. As of the beginning of the thirteenth century, it seems as if the cathedral chapters alone performed episcopal elections, without the participation of viri religiosi. The process entailed a gradual "de-monasticization" of cathedral culture. The intervention by Pope Honorius III in connection with the election of Peder Sakseson in 1224 clearly demonstrates how the freedom and purity of the Church was no longer safeguarded by monastic ideals but instead through legal control and administrative measures. In this new milieu, the cathedral chapters were objects and instruments of control as well as agents in their own right.

\section{Lund University}

Keywords: Canon Law, Episcopal elections, Denmark, Lateran Councils, Cathedral chapters

109 Cf. Becker and Dubois, "Kapitel" (n. 49 above); Jerome Bertram, Vita Communis: The Common Life of the Secular Clergy (Leominster, 2009), 124-39. On the Austin friars, see John Compton Dickinson, The Origins of Austin Canons and Their Introduction into England (London, 1950).

110 Buus, "Indledning" (n. 63 above), 118; Borgehammar, "Liber daticus vetustior" (n. 73 above), 111-14, 117-18.

111 Cf. Bertram, Vita Communis, 140-62. 